LAND REFORM, POVERTY REDUCTION AND GROWTH: EVIDENCE FROM INDIA

BY

TIMOTHY BESLEY AND ROBIN BURGESS*

London School of Economics

Houghton Street

London WC2A $2 \mathrm{AE}$

This Draft: September 1998

DEDPS No. 13

October 1998
The Development Economics Discussion Paper Series The Suntory Centre Suntory and Toyota International Centres for Economics and Related Disciplines London School of Economics Houghton Street London WC2A $2 \mathrm{AE}$ Tel: 01719556698

\footnotetext{
* The authors are grateful to Ahbijit Banerjee, Pranab Bardhan, Clive Bell, Francois Bourguignon, Jean Dreze, Michael Lipton, Rohini Pande, Martin Ravallion and a number of seminar participants for helpful comments. Timo Henckel and Cecilia Testa provided able research assistance. We also thank STICERD for invaluable financial support.
} 


\title{
LAND REFORM, POVERTY REDUCTION AND GROWTH: EVIDENCE FROM INDIA
}

$\underline{\text { BY }}$

\author{
TIMOTHY BESLEY AND ROBIN BURGESS \\ London School of Economics \\ Houghton Street \\ London WC2A 2AE
}

This Draft: September 1998

\begin{abstract}
In recent times there has been a renewed interest in relationships between redistribution, growth and welfare. Land reforms have been central to strategies to improve the asset base of the poor in developing countries thought their effectiveness has been hindered by political constraints on implementation. In this paper we use panel data on the sixteen main Indian states from 1958 to 1992 to consider whether the large volume of land reforms as have been legislated have had an appreciable impact on growth and poverty. The evidence presented suggests that land reforms do appear to be associated with poverty reduction.
\end{abstract}

Keywords: land reform, political economy, poverty, growth, India

JEL Classification: D60, H11 O11, Q15, R11

(C) by Timothy Besley and Robin Burgess. All rights reserved. Short sections of text, not to exceed two paragraphs, may be quoted without explicit permission provided that full credit, including (C) notice, is given to the source. 


\title{
Land Reform, Poverty Reduction and Growth: Evidence from India
}

\author{
Timothy Besley and Robin Burgess* \\ London School of Economics \\ Houghton Street \\ London WC2A 2AE
}

This Draft: September 1998

\begin{abstract}
In recent times there has been a renewed interest in relationships between redistribution, growth and welfare. Land reforms have been central to strategies to improve the asset base of the poor in developing countries though their effectiveness has been hindered by political constraints on implementation. In this paper we use panel data on the sixteen main Indian states from 1958 to 1992 to consider whether the large volume of land reforms as have been legislated have had an appreciable impact on growth and poverty. The evidence presented suggests that land reforms do appear to be associated with poverty reduction.
\end{abstract}

*The authors are grateful to Ahbijit Banerjee, Pranab Bardhan, Clive Bell, Francois Bourguignon, Jean Dreze, Michael Lipton, Rohini Pande, Martin Ravallion and a number of seminar participants for helpful comments. Timo Henckel and Cecilia Testa provided able research assistance. We also thank STICERD for invaluable financial support. 


\section{Introduction}

Finding effective means to relieve poverty is a defining mission for development economics. To this end, a wide range of policy alternatives have been implemented. However, the benefits of many such efforts have been questioned. Some argue that political constraints on implementation deny the poor the benefits of redistributive efforts. Others suggest that benefits to the poor are undermined by disincentives to generate income. Worse still, these disincentives can afflict the non-poor who try to qualify for assistance. This in turn leads policy analysts to question the wisdom of implementing redistributive policies at all, focusing instead on policies that promote economic growth. Combatting such pessimism requires empirical evidence that some redistributive policies have achieved their stated goals.

This paper studies land reform as a redistributive policy. Throughout the post-colonial period, improvement in the asset base of the poor has been viewed as a central strategy to relieve endemic poverty (Chenery et al., 1970). In a poor agrarian economy, typical of those in many less developed countries, this implies improving the terms on which the poor have access to land. Significant political changes, such as decolonization, have sometimes afforded the opportunity to undertake far-reaching land reforms that transfer property rights to the poor. However, such instances are rare and more incremental measures are common. This is the case in India where land reforms have been on the policy agenda since independence. These reforms have involved only limited efforts at land redistribution, mostly through legislated ceilings on land holding. Legislation aimed at regulating tenancies, for example by improving tenurial security, and reducing the power of absentee landlords and intermediaries are more common. While the latter need not change the distribution of land holdings, they may improve tenants' claims to the returns from their land. This may also benefit the landless by raising agricultural wages.

India is an important case study of land reform. It is both home to a significant fraction of the poor in the developing world and in the post-Independence period was subjected to the largest body of land reform legislation ever to have been passed in so short a period in any country (Thorner, 1976). The efficacy of this legislation has, however, been much debated. The conventional wisdom following the influential commentary of Bardhan (1970) is that, while land reform legislation abounds, the real impact on the conditions of the poor is muted by unenthusiastic implementation of proposed changes. However, broad based quantitative testing 
of this notion does not appear to have been attempted previously. This paper takes advantage of the state level panel data available for the sixteen main Indian states from 1958 to 1992 to assess this. The state is the natural unit of analysis for land reform given that state governments have jurisdiction over land reform legislation. The relatively long time period covered by the data also allows respectable efforts to deal with some econometric concerns. Our principal finding is that land reforms do appear to have lead to reductions in poverty in India. This finding is robust to a number of methods of estimation, and the inclusion/exclusion of many different controls.

We also use our data to investigate the relationship between land reform and growth. The recent growth literature has debated whether efforts by government to redistribute necessarily result in lower growth. This argument is formalized in Alesina and Rodrik (1994) and Persson and Tabellini (1995) who find evidence of a negative relationship between redistribution and growth implied by the theory in a political economy context. This argument can, however, be questioned on theoretical grounds in a world of incomplete markets as redistribution can alter the terms of agency problems in credit markets and foster accumulation decisions - see for example, Hoff and Lyon (1995) and Benabou (1996). This suggests that there can even be a positive relationship between redistributive efforts and economic growth. Most existing empirical evidence comes from cross-country data. While informative, there are insurmountable problems of comparability of data across countries and assessing directions of causation. The fact that our data come from one country with similar data collection strategies in each state, and the relatively long time period, allow us to make progress on this.

Empirical studies of the impact of land reform are rare since reliable estimation requires data from the pre- and post- reform periods. In India, there are numerous case studies of land reform (reviewed below), but few attempts to look at the overall picture. Discussion of the theoretical impact of land reform have been dominated by the frequently found inverse farm size-productivity relationship, whence small farmers are supposed to achieve higher yields (see Binswanger et al 1995). This suggests that finding means of evening the distribution of land holding should lead to productivity gains in addition to redistributive benefits. However, land reforms in India are rarely of a form that could directly exploit this possibility. Moreover, careful theoretical analysis, as in Banerjee and Ghatak (1997) shows that the theoretical effects on productivity are inherently ambiguous when assessing the impact of tenancy reforms that allow tenants greater security.

The remainder of the paper is organized as follows. The next section discusses 
background and data issues. Section 3 examines the impact that land reforms have had on poverty and deals with potential problems in interpreting the basic results. Section 4 addresses issue as to whether land reforms can have general equilibrium effects by examing their impact on agricultural wages. Section 5 then turns to the issue of how land reforms have affected economic growth. In Section 6 we develop a theoretical framework which allows us to interpret our results in the light of the literature on land reform. Finally, section seven concludes.

\section{Background and Data}

Under the 1949 Indian constitution, states were granted the powers to enact (and implement) land reforms. This autonomy ensures that there has been significant variation across states and time in terms of the number and types of land reforms that have been enacted (see Table 1). We classify land reform acts into four main categories according to their main purpose (see Mearns, 1998). The first category is acts related to tenancy reform. These include attempts to regulate tenancy contracts both via registration and stipulation of contractual terms, such as shares in share tenancy contracts, as well as attempts to abolish tenancy and transfer ownership to tenants. The second category of land reform acts are attempts to abolish intermediaries. These intermediaries who worked under feudal lords (Zamandari)to collect rent for the British were reputed to allow a larger share of the surplus from the land to be extracted from tenants. Most states had passed legislation to abolish intermediaries prior to 1958. However, five (Gujarat, Kerala, Orissa, Rajasthan, Uttar Pradesh) did so during our data period. The third category of land reform acts concerned efforts to implement ceilings on land holdings, with a view to redistributing surplus land to the landless. Finally, we have acts which attempted to allow consolidation of disparate land-holdings. ${ }^{1}$ Though these reforms and in particular the latter were justified partly in terms of achieving efficiency gains in agriculture it is clear from the acts themselves and from the political manifestos supporting the acts that the main impetus driving the first three reforms was poverty reduction. It is therefore of some interest, from the perspective of public policy, to assess whether these reforms were effective in achieving their stated aims.

Existing assessments of the effectiveness of these different reforms are highly mixed. Though promoted by the centre in various Five Year Plans, the fact that

\footnotetext{
${ }^{1}$ In theory anyway these reforms should be distributionally neutral.
} 
land reforms were a state subject under the 1949 Constitution meant that enactment and implementation was dependent on the political will of state governments (Bandyopadhyay, 1986; Radhakrishnan, 1990; Appu, 1996; Mearns, 1998). The perceived oppressive character of the Zamandari (and their intermediaries) and their close alliance with the British galvanized broad political support for the abolition intermediaries and led to widespread implementation of these reforms most of which were complete by the early 1960s (Appu, 1996; Mearns, 1998). ${ }^{2}$ Centrestate alignment on the issue of tenancy reforms was much less pronounced. ${ }^{3}$ With many state legislatures controlled by the landlord class, reforms which harmed this class tended to be blocked though where tenants had substantial political representation notable successes in implementation were recorded. Despite the considerable publicity attached to their enactment, political failure to implement was most complete in the case of land ceiling legislation. Here ambivalence in the formulation of policy and numerous loopholes allowed the bulk of landowners to avoid expropriation by distributing surplus land to relations, friends and dependents (Appu, 1996; Mearns, 1998). As a result of these problems, implementation of both tenancy reform and land ceiling legislation tended to lag well behind the targets set in the Five Year Plans (Bandyopadhyay, 1986; Radhakrishnan, 1990) ${ }^{4}$. Land consolidation legislation was enacted less than the other reforms and, owing partly to the sparseness of land records, implementation has been considered to be both sporadic and patchy only affecting a few states in any significant way ( Radhakrishnan, 1990; Appu, 1996; Mearns, 1998).

Village level studies also offer a very mixed assessment of the poverty impact of different land reforms (see Jayaraman and Lanjouw, 1997). Similar reforms seemed to have produced different effects in different areas leaving overall impact indeterminate. There is some consensus that the abolition of intermediaries achieved a limited and variable success both in redistributing land towards the poor and increasing the security of smallholders (see e.g. Wadley and Derr, 1990).

\footnotetext{
${ }^{2}$ There was nonetheless some major design flaws most notably the failure to limit the size of home farms of Zamindars or to protect short-term tenants.

${ }^{3}$ As Warriner (1969) commented Congress "provided both the motivation for land reform and the opposition to it, as a socialist head with a conservative body".

${ }^{4}$ The Fifth Plan gives a frank assessment of the situation which is directly in line with that of Bardhan (1970): "A broad assessement of the programme of land reform adopted since Independence is that the laws for the abolition of intermediary tenures have been implemented fairly efficiently whilst in the fields of tenancy reforms and cielings on holdings, legislation has fallen short of the desired objectives, and implementation of the enacted laws has be inadequate (Fifth Five Year Plan, 1974-79, 2: 43).
} 
For tenancy reform, however, whereas successes have been recorded, in particular, where tenants are well organized there has also been a range of documented cases of imminent legislation prompting landlords to engage in mass evictions of tenants and of the de jure banning of landlord-tenant relationships pushing tenancy underground and therefore, paradoxically, reducing tenurial security (see e.g. Gough, 1987). Land ceiling legislation, in a variety village studies, is also perceived to have had neutral or negative effects on poverty by inducing landowners from joint families to evict their tenants and to separate their holdings into smaller proprietary units among family members as a means of avoiding expropriation (see e.g. Chattopadhyay, 1994). Land consolidation is also on the whole judged not to have been progressive in its redistributive impact given that richer farmers tend to use their power to obtain improved holdings (see e.g. Dreze, Lanjouw and Sharma, 1997).

Table 2 gives a complete picture of land reform in our data period. It also gives our classification of each reform. We make use of these data in our quantitative analysis by recording the year and state in which a particular reform is passed. The variable thus captures the impact of legislated as opposed to implemented land reforms. Since land reforms are likely to have effects over time and not necessarily in their year of passage, we measure the extent of reform since the beginning of our data period by a cumulative variable that aggregates the number of legislative reforms to date. While crude, we believe that it provides a sensible first pass at analyzing the quantitative effects of land reform. The mean of that variable aggregated across the four categories of land reform is given in Table 1 column 5. This shows that there is a considerable variation in overall land reform activity across states with states such as Uttar Pradesh, Kerala and Tamil Nadu having a lot of activity while Punjab and Rajasthan have very little.

Our poverty outcome data come from a new and consistent set of figures for the rural and urban areas of India's sixteen major states spanning the period 19581992 compiled by Ozler, Datt and Ravallion (1996). ${ }^{5}$ The measures are based on consumption distributions from 21 rounds of the National Sample Survey (NSS) spanning this period. The poverty line is based on a nutritional norm of 2400 calories per day and is defined as the level of average per capita total expenditure at which this norm is typically attained. Two poverty measures are considered the head count index $(H)$ and the poverty gap $(P G)$ measure. Given that NSS surveys are not annual, weighted interpolation has been used to obtain values

\footnotetext{
${ }^{5}$ We are grateful to Martin Ravallion for providing us with this data.
} 
between surveys. ${ }^{6}$ Our study should be seen in the context of a significant overall reduction in poverty throughout our data period - the all-India rural head count measure has fallen from around $55 \%$ to $40 \%$ and the rural poverty gap from $19 \%$ to around $10 \%$. That said, there is considerable cross-sectional variation in performance across states. ${ }^{7}$ Agricultural wage data were also collected to enable us to examine whether land reforms had general equilibrium affects and were thus capable reaching groups of the poor (e.g. landless) who did not directly benefit from the reforms.

Real values of per capita agricultural, non-agricultural and combined state domestic product were used to examine the determinants of growth. Agricultural state domestic product was deflated using the Consumer Price Index for Agricultural Laborers while the Consumer Price Index for Industrial Workers was used to deflate the non-agricultural state domestic product. We also constructed a variable to measure agricultural yields. This was defined as real agricultural state domestic product divided by the net sown area. This crudely captures technological changes in agriculture.

Public finance data at the state level were also collected chiefly as a means to control for other government interventions besides land reform. On the expenditure side, the main classification available for our data period is into development and non-development expenditure. While development expenditure does include expenditure on economic and social services, there is no particular connection between this category and government's efforts to develop the population or infrastructure in their states. ${ }^{8}$ Development expenditures are therefore further disaggregated into health and education expenditures which we might expect to have appreciable impacts on poverty. ${ }^{9}$ We put these in real terms and measure them in per capita terms. We also collected total state taxes as a share of state GDP as a crude measure of the size of state governments and state redistributive

\footnotetext{
${ }^{6}$ Below, we check that our results are robust to including only those years where there was an NSS survey round.

${ }^{7}$ See Datt and Ravallion (1998) for further discussion.

${ }^{8}$ Economic services include agriculture and allied activities, rural development, special area programs, irrigation and flood control, energy, industry and minerals, transport and communications, science, technology and environment. Social services include education, medical and public health, family welfare, water supply and sanitation, housing, urban development, labour and labour welfare, social security and welfare, nutrition and relief on account of natural calamaties.

${ }^{9} \mathrm{~A}$ range of other interventions in other arenas were also considered.
} 
taxes per capita ${ }^{10}$ to capture the effort of state governments to redistribute from rich to poor. Population estimates from the five censuses for 1951, 1961, 1971, 1981 and 1991 were used as additional controls. Between any two censuses these were assumed to grow at a constant (compound) rate of growth, derived from the respective population totals.

\section{Land Reform and Poverty Reduction}

\subsection{Basic Results}

The empirical approach is to run panel data regressions of the form:

$$
x_{s t}=\alpha_{s}+\beta_{t}+\gamma y_{s t}+\psi l_{s t-4}+\varepsilon_{s t}
$$

where $x_{s t}$ is some measure of poverty in state $s$ at time $t, \alpha_{s}$ is a state fixed effect, $\beta_{t}$ is a year dummy variable, $y_{s t}$ is a vector of variables that we treat as exogenous (detailed below), $l_{s t-4}$ is the stock of past land reforms four periods previously and $\varepsilon_{s t}$ is an error term which we model as $\operatorname{AR}(1)$ process where the degree of auto-correlation is state-specific, i.e., $\varepsilon_{s t}=\rho_{s} \varepsilon_{s t-1}+u_{s t}$. Estimation via generalized least squares will also allow for a heteroskedasticity in error structure with each state having its own error variance.

Equation (3.1) is a reduced form model of the impact of land reform. Thus any effect of land reform on poverty is picked up by that variable along with other effects that change the claims that tenants have to land. The land reform variable will also pick up any general equilibrium effects of land reform through changes in wages and prices. Below, we discuss what kind of theoretical model is consistent with our empirical findings.

The approach is also reduced form because land reform legislation is used as regressor. We are unable to measure whether land reforms are actually implemented. We cannot distinguish, therefore, between ineffective and unimplemented land reforms. Even, though we have no measure of this, there is anecdotal evidence that some land reforms were not fully implemented. Hence, the coefficient on land reform in (3.1) is likely to provide a lower bound on the true effect of an implemented land reform. We have lagged the land reform variable four periods for two main reasons. First, it seems reasonable to suppose that even effective legislation will take time to be implemented and to have an impact. Second, it

\footnotetext{
${ }^{10}$ These include land tax, agricultural income tax and property tax all of which are under the control of state governments.
} 
may help to allay concerns that shocks to poverty will be correlated with land reform efforts, an issue to which we return below. Fixed effects at the state level control for usual array of cross state differences in history and economic structure that have been constant over our sample period, while the year effects cover for macro-shocks and policies enacted by the central government that affect poverty and growth.

Table 3 gives the basic picture from our data. In column (1) we control for other factors affecting poverty only by using state and year effects. Land reform is represented only by the cumulative land reform variable where all types of land reforms are aggregated. The negative and significant association between land reform and the rural poverty gap measure is clear from this. Column (2) confirms that this result is not sensitive to using the interpolated years when there were no NSS rounds. In column (3) land reforms are disaggregated into their component types, also lagged four periods. This suggests that tenancy reforms and the abolition of intermediaries are driving the aggregate effects, while land ceiling legislation and consolidation of landholdings have a negligible impact on rural poverty. Below, we will suggest a theoretical interpretation of the results that is consistent with this finding. The fact that land ceiling legislation is unimportant confirms anecdotal accounts of the failure to implement these reform measures in any serious way (Bardhan, 1970; Appu, 1996; Mearns, 1998). Column (4) checks the sensitivity of the findings to using an alternative measure of poverty - the head count ratio. A similar negative impact of tenancy reform and the abolition of intermediaries on poverty is found here. ${ }^{11}$

If land reform is really responsible for these results (rather than some omitted variable that is correlated with land reform), then we would not expect to see such effects on urban poverty. There is no good reason to think production and distribution decisions in the urban sector would be affected (apart from some complex general equilibrium reasons). This is confirmed in column (5) of Table 3 which finds no significant negative association between land reform and urban poverty as measured by the same NSS data. This adds credence to the idea that our land reform variable is picking up something peculiar to the rural sector.

Columns (6) to (8) tries a different approach. Using our finding in column (5) that urban poverty does not respond to land reform, we use the difference between rural and urban poverty as a regressor. This helps to control for any omitted variables that have common effects on poverty in both places. In column

\footnotetext{
${ }^{11}$ Using headcount in place of the poverty gap does not significantly effect any of our results on land reform and poverty.
} 
(6) we confirm that aggregate cumulative land reforms lagged four periods have played a significant role in reducing the gap between the rural poverty gap and the urban poverty gap. Results broken out by type of land reform are consistent with those for rural poverty: tenancy reforms and the abolition of intermediaries have had a significant impact in closing rural-urban poverty gap whilst the impact of the other the two types of land reform are insignificant (column 7). Using the gap between rural and urban head counts does not affect the results in any significant way (column 8).

Taken together these results demonstrate a consistent picture. Land reform in general appears to be associated with reductions in rural poverty, with these effects most strongly associated with land reforms that seek to abolish intermediaries and reform the conditions of tenancies.

\subsection{Robustness}

While these results are clean, they leave two significant concerns unmet. First, they make no effort to allow for other policies to affect poverty. In particular, we might be concerned that land reform is simply proxying for other policies that are correlated with poverty reduction. Second, land reform could be endogenous and responding to the same forces that drive poverty. We now address both of these concerns.

\subsubsection{Other Policies}

Table 4 reports results that include an array of additional controls. All regressions now include the population growth rate and agricultural yield lagged four periods. The latter may proxy for other policies that could have enhanced agricultural productivity and are correlated with land reform. It may also pick up exogenous technological change. Our policy measures are in two categories: reflecting the expenditure and tax policies of state governments. Our expenditure variables are health expenditures per capita, education expenditures per capita and other expenditures per capita. ${ }^{12}$ The former two might be thought to be important determinants of poverty reduction efforts. ${ }^{13}$ On the tax side, we have two rather crude measures which give a picture of the general policy stance of the government in office. State taxes expressed as a share of state domestic product crudely serve

\footnotetext{
${ }^{12}$ That is total expenditure excluding health and education.

${ }^{13}$ In earlier regressions we included a much larger array of controls for government expenditure including those on food security, famine, rural infrastructure and other social services.
} 
to measure the size of the state government. We can also measure how much the government is intent on designing a tax system that is geared towards taxing the better off. We create a measure of the progressiveness of the tax system under state control. This is the sum of land taxes, agricultural income taxes and property taxes expressed per capita. ${ }^{14}$ All policy variables are lagged four periods to give the same timing structure as the land reform variables and to minimize concerns about the possible endogeneity of these policy variables.

In columns (1)-(6) of Table 4 we replicate the regressions of land reform on poverty including these other policies. Irrespective of specification state redistributive taxes, state tax share, and yield exert significant negative impacts on rural poverty whereas education, health and residual expenditure per capita and population growth are generally insignificant at conventional levels. ${ }^{15}$ In column (1) we include the full set of policy control variables in the basic regression of cumulative land reform on the rural poverty gap measure. Despite controlling for these many dimensions of state activity, cumulative land reform continues to exert a negative and significant impact on rural poverty. ${ }^{16}$ In column (2) we run the same regression while disaggregating the land reform variable. We continue to find that tenancy reforms and the abolition of intermediaries exert a negative and significant impact on the rural poverty gap measure whereas land ceiling and land consolidation legislation exert no significant influence. Replacing the poverty gap measure with the head count measure as is done in column (3) produces a similar set of results. When we examine the urban poverty regression (column 4) we find that, in common with the rural poverty regressions, health and education expenditure have no significant impact and tax share and yield have significant impacts. The latter suggests that there might be some link between rural technological improvement and urban poverty which is worthy of further investigation. ${ }^{17}$ State redistributive taxes are insignificant in this regression suggesting that their

\footnotetext{
${ }^{14}$ Again, much finer disaggregations of taxes were included in earlier regressions.

${ }^{15}$ The expenditure results are interesting given the priority attached, in current debates, to expansion of expenditures on education and health as a key means of reducing poverty (see Dreze and Sen, 1995). However, it is possible that we would needer finer measures of the ways in which particular programs are prioritized to make progress on this.

${ }^{16}$ We experimented with regressions including a larger set of public finance variables pertaining to specific areas relevant to the determination of poverty. In all cases the negative and significant impact of land reform on rural poverty remained intact.

${ }^{17}$ We also find that yield and non-agricultural income per capita are positively related. This is reminiscent of the literature that has suggested that agricultural growth is a stimulus to non-agricultural growth.
} 
impact is restricted to the rural sector. Inclusion of these extra variables has no effect on the insignificant impact of cumulative land reform on urban poverty.

Again exploiting this differential impact of land reform we run in columns (5) and (6) regressions of the difference between rural and urban poverty on cumulative land reform and the full set of control variables. Note that compared to column (1) of this table, only the land reform variable and state redistributive taxes remain significant suggesting that they have a role in closing the rural-urban poverty gap. Other effects appear to be common to both rural and urban sectors and are therefore insignificant in this regression. Contrasting columns (5) and (6) confirms that results are robust to the type of poverty measure being used. Taken together the results presented in Table 4 offers further confirmation of our initial finding of a significant negative association between lagged land reform and rural poverty.

\subsubsection{Endogeneity}

Equation (3.1) has no structural interpretation and as a specification it raises a number of concerns. Central among these is the potential endogeneity of the land reform variable. If land reform is purposefully aimed at poverty reduction, then we would expect to policy effort focus where poverty is highest. We would expect this to bias the coefficient on the land reform variable downward, other things being equal. While, lagging land reform as we have in (3.1) goes some way towards minimizing concerns about this, there is some residual concern that long lived shocks to poverty that affect anti-poverty legislation could bias the results.

To fix this problem requires an instrument for land reform. To this end, we exploit the fact that land reform is intensely political, with different groupings in state legislatures (the Vidhan Sabha) being more likely to enact land reform legislation. However, this can be problematic if, as seems likely, shocks to poverty affect who is elected. To mitigate this problem, we propose using long lags of the political variables as instruments for land reform. Specifically, political variables from four periods prior to the land reform (eight periods before the poverty observation) are used as an instrument for land reform. This is legitimate provided that contemporaneous shocks to poverty are uncorrelated with shocks that lead to particular groups being elected eight years previously. Such an assumption seems defensible given both the frequency of elections and policy shifts in India and because it is difficult to think of long lasting shocks affecting both current poverty and political structure eight years ago. 
This strategy implies a first stage equation for land reform:

$$
l_{s t}=\mu l_{s t-4}+a_{s}+b_{t}+c y_{s t}+d z_{s t-4}+\eta_{s t}
$$

where $l_{s t}$ is the land reform variable that we discussed above, $a_{s}$ is a state fixed effect, $b_{t}$ is a year dummy variable, $y_{s t}$ is a vector of variables which we treat as exogenous, the variables $z_{s t-4}$ are political variables reflecting the seat shares of different political groups, each lagged by four years. These are constructed from records of the number of seats won by different national parties at each of the state elections under five broad groupings. (The parties contained in the relevant group are given in parentheses after the name of the grouping.) These are: (i) Congress Party (Indian National Congress + Indian Congress Socialist + Indian National Congress Urs + Indian National Congress Organization), (iii) a hard left grouping (Communist Party of India + Communist Party of India Marxist), (iv) a soft left grouping (Socialist Party + Praja Socialist Party), (v) Hindu parties (Bhartiya Janata Party + Bhartiya Jana Sangh), (vi) Janata parties (Janata Party, Janata Dal Party + Lok Dal Party). ${ }^{18}$ We express these as a share of total seats in the legislature. Congress has tended to dominate the assemblies over the period though hard left parties have also recorded majorities in Kerala and West Bengal and Janata parties in Bihar, Haryana, Karnataka, Madya Pradesh, Rajastan and Uttar Pradesh. Over time there has been a decline in the importance of Congress and a rise in the importance of religious and regional parties.

Table 5 presents estimates of equation (3.2) for the different kinds of land reforms. The overall picture is one in which political variables matter for land reform legislation. The political variables are jointly significant determinants of cumulative land reforms over the period. In column (1) we see that, relative to the omitted "other" category, which is composed of a amalgam of regional, independent parties and the Janata parties, Congress and soft left decrease the probability of enacting of land reform legislation while hard left exerts a positive influence and Hindu parties are insignificant. Looking across columns (2) to (5) we see the negative influence of Congress is spread across all types of land reform but it particularly pronounced for tenancy reforms and abolition of intermediaries. The negative influence of soft left parties is also spread across the board with

\footnotetext{
${ }^{18}$ The latter category is not included separately in our regressions, but is included in the "other" category. This was in part due to concerns stemming from our overidentification tests which passed only marginally when the Janata parties were included in the instrument set. This suggests that the political mood swings that have lead to greater prominence of the Janata parties in certain states appear to be correlated with trends in poverty.
} 
the exception of land consolidation. The overall positive influence of hard left parties, however, seems to originate principally through a strong positive effect on the passage of land cieling legislation. This is interesting given our failure to find evidence that such reforms reduce poverty. Hindu party representation appears to exert no influence on the passage of tenancy reforms or the abolition of intermediaries, however, they exert a significant positive influence on land ceiling and a significant negative influence on land consolidation effect which helps to explain their overall insignificant effect in column (1).

Table 6 gives results that instrument land reform using these eight period lagged political variables. In column (1) we find that instrumented cumulative land reform continues to have a negative and significant impact on the rural poverty gap. The same result is found for the rural headcount in column (2). In column (3) and (4), using the poverty gap and headcount respectively, we break out land reforms by type and find that both tenancy reforms and abolition of intermediaries remain negative and significant whilst other types of land reform are insignificant. ${ }^{19}$ Columns (4) and (5) confirm that land reform still has a significant impact in closing the gaps between the rural and urban poverty. The overall pattern is thus consistent with the patterns of results shown in Tables 3 and 4.

We also report tests of our overidentifying restrictions for the instrumental variables regressions. The political variables pass standard statistical tests of over identification and therefore at least on econometric grounds would appear to be suitable instruments for land reforms. ${ }^{20}$ Table 6 is best thought of as a robustness check on our findings rather than a carefully thought out structural model. The overall impression is that our results stand up to this procedure with land reforms in general and tenancy reforms and the abolition of intermediaries in particular continuing to be associated with poverty reduction.

\subsection{Land Reform and Agricultural Wages}

It would be surprising if land reforms that affected poverty did not impact on other aspects of the rural economy. In this sub-section, we consider the possibility that such reforms have an effect on agricultural wages. Agricultural wages are a robust indicator of the welfare of landless labourers which comprise a significant fraction

\footnotetext{
${ }^{19}$ With the exception of land cielings in column (3).

${ }^{20}$ The test we employ which is also known as the Sargan test after Sargan (1958) tests whether the instruments are correlated with residuals from the second stage regression (see Davidson and McKinnon, 1993).
} 
of the poor in rural India (see World Bank, 1997). If land reform pushes up agricultural wages this represents an additional mechanism through which these reforms can reduce rural poverty.

The results using the agricultural wage as a left hand side variable are in Table 7. Column (1) contains results for the aggregate land reform variable. This demontrates a positive and significant impact of land reform on wages. In column (2), this effect is disaggregated across types of land reform and shows that this effect is primarily attributable to legislation to abolish intermediaries. Given that the wage data are from a completely independent data source ${ }^{21}$ these results help to confirm that land reforms are having real effects on the functioning of the rural economy. They also illustrate an indirect route through which land reform may positively affect the welfare of landless labourers who do not directly benefit from the reforms. In section 6 below, we discuss why such effects might be present in theory.

\subsection{Land Reform and Growth}

Even if land reform does help the poor, it could do so at a cost to economic performance. We turn now, therefore, to exploring whether land reform has a positive or negative affect on agricultural output per capita. In this case, we use log agricultural state domestic product per capita as the left hand side variable in (3.2) with the right-hand side augmented by lagged log state domestic product per capita to model dynamics in a very simple way and to allow for convergence over time. We therefore have a regression of the form:

$$
x_{s t}=\lambda x_{s t-1}+\alpha_{s}+\beta_{t}+\gamma y_{s t}+\psi l_{s t-4}+\varepsilon_{s t}
$$

This is basically the same form of regression that has become popular in the crosscountry growth literature summarized in Barro (1997), although our panel data allow us to use fixed effects and year effects. We will also continue to allow for a state specific $\mathrm{AR}(1)$ error specification with some degree of heteroskedasticity.

Table 8 presents the main results for the regression of state income per capita on cumulative land reform. In column (1) we present results for a GLS model of total state income per capita on land reform containing only state fixed effects and

\footnotetext{
${ }^{21}$ The wage data are from Ozler, Datt and Ravallion (1996). The primary original source for this data is the Ministry of Agriculture annual publication "Agricultural Wages in India". Nominal wage data from this series has been deflated using the Consumer Price Index for Agricultural Laborers to obtain real agricultural wages.
} 
year effects as controls. We find that the disaggregated land reform variable lagged four periods has no significant impact on income per capita. In column (2) we look only at agricultural income per capita. This makes sense given that land reform is predominantly concerned with affecting production relations in agriculture. This suggests that tenancy reform has a negative effect on agricultural output with land consolidation having the opposite effect. No effect is observed for the other kinds of land reform. Column (3) shows that both the tenancy reform and land consolidation effects are robust to including our other policy variables lagged four years. In column (4), we show that these effects remains when agricultural yields rather than income per capita is the left hand side variable. In column (5) we show that the effect of tenancy reform (but not land consolidation) is robust to including other policy variables.

\subsection{Summary}

Taken together these results give some suggestion of an equity-efficiency tradeoff for tenancy reforms since both poverty and output per capita are lower after such reforms are enacted. No such trade-off emerges for abolition of intermediaries. Ceilings on land holdings do not seem to have an effect on either output measures or poverty, while land consolidation promotes output increases in agriculture without affecting poverty. The failure of land ceiling legislation to show any significant impact on poverty reduction or output levels is consistent with Bardhan (1970)'s claim that such reforms have rarely been implemented with any degree of seriousness.

Impacts on poverty therefore appear to be coming mainly through reforms that affect production relations but do not directly alter the distribution of land. This interpretation is underlined by looking at the limited evidence available on the relationship between land reforms and land distribution over our data period. Data on land distribution has only been gathered by NSS special surveys at four points; 1953-54, 1961-62, 1971-72 and 1982 (see Sharma, 1994). We classify states as high or low land reform depending on whether they had more or less than a total of three land reforms (of any type) during the 1958-92 period. ${ }^{22}$ We then investigate whether high land reform states classified in this way experienced the largest drop in the Gini for land operated and proportion of landless households

\footnotetext{
${ }^{22}$ Under this system Andra Pradesh, Assam, Haryana, Jammu and Kashmir, Madya Pradesh, Maharashtra, Punjab and Rajasthan are low land reform states whilst Bihar, Gujarat, Karnataka, Kerala, Orissa, Tamil Nadu, Uttar Pradesh and West Bengal are high land reform states.
} 
over the period. ${ }^{23}$ The overall impression that we have from this crude exercise, is of persistent inequalities in land operated within both groups of states (see also Sharma, 1994). Thus the idea that the major impact of land reform on poverty must come mainly through mechanisms that did not involve land redistribution gains further support. Thus in making sense of the results, it is imperative to think about land reforms that have changed production relations in agriculture rather than altering the pattern of land holdings.

\section{Making Sense of the Results}

Our empirical analysis suggests that poverty reduction is associated with land reform and this is primarily attributable to legislation that has abolished intermediaries and reformed the terms of tenancies. The role of land redistribution per se seems to have been of limited importance in the Indian context. The empirical analysis also uncovers some evidence of general equilibrium effects on wages. Our theoretical model focuses on two things: a model of agricultural contracting and a model of labor supply by tenants. The former focuses on how rents to tenants shift in response to land reforms and the latter gives rise to effects on agricultural wages.

There are three groups: landlords who rent out land as well as farming some of the land themselves, tenants who rent land, and landless laborers. The poor are made up predominantly of the latter two groups. Tenants and landless laborers supply labor to the labor market where it is demanded by landlords who choose to be owner-cultivators. Tenants and landless laborers care about consumption, $\mathrm{c}$, and labor supply $\ell$. Their preferences are $u(c)-\phi(\ell)$, where $u(\cdot)$ is increasing and concave and $\phi(\cdot)$ is increasing and convex. Suppose that the agricultural wage is $\omega$. Then, an individual with non-labor income $x$, has optimal labor supply of

$$
\ell^{*}(x, \omega)=\underset{\ell}{\arg \max }\{u(x+\omega \ell)-\phi(\ell)\} .
$$

It is straightforward to check that labor supply is decreasing in $x$. Now define $v(x, \omega)=u\left(x+\omega \ell^{*}(x, \omega)\right)-\phi\left(\ell^{*}(x, \omega)\right)$ as the indirect utility of a tenant with non-labor income $x$. Hence, we expect landless laborers to supply $\ell^{*}(0, \omega)$, while

\footnotetext{
${ }^{23}$ For high land reform states the land gini falls from 0.686 in 1953/54 to 0.669 in 1982 (a fall of 0.017 ) whereas the drop in low land reform states is from 0.653 to 0.643 (a drop of 0.010 ). For high land reform states the average drop in the proportion landless is from $14.97 \%$ ro $12.03 \%$ (a fall of 2.94\%) whereas for low land reform states the drop is from $12.40 \%$ to $10.91 \%$ (a fall of $1.49 \%$ ).
} 
for tenants $x$ is equal to the value of their tenancy. As the value of tenancy increases as result of land reform we would therefore expect tenants to reduce labour supply to the market.

We now consider the agricultural contracting problem of a tenant and landlord. Suppose that the output on a given piece of land under tenancy is given by $R(e)$ where $e$ denotes effort applied to the land by the tenant. We suppose that the cost of this effort is separable from labor supply and is measured in units of disutility. Effort is also committed before the labor supply decision is made. We assume that $R(\cdot)$ is smooth, increasing and concave.

We suppose that tenants need to be monitored in order to put in effort on the land. Specifically, we imagine that a contract specifies an effort level of $e$. However, the tenant may choose to "shirk", putting in zero effort, in which case the landlord catches him with probability $p$ and he is fired, becoming a landless laborer and receiving a payoff of $v(0)$. The tenant can now only be induced to supply effort if the threat of eviction is sufficiently strong and some rents are earned from being a tenant. Suppose then, that the tenant receives a payment of $w$ to farm the land, which he receives only if he is not caught shirking. Thus a tenant is willing to put in an effort level $e$ at payment $w$ if and only the incentive constraint $(1-p) v(w, \omega)+p v(0, \omega) \leq v(w, \omega)-e$ is satisfied. Solving this as an equality gives the payment schedule $w(e)$ needed to induce effort level $e$ as

$$
w(e, \omega)=v^{-1}\left(v(0, \omega)+\frac{e}{p}\right) .
$$

The contract must now specify a payment/effort pair consistent with this schedule. The optimal effort that the landlord choose to induce is given by

$$
e(p)=\arg \max _{e}=\{R(e)-w(e, \omega)\}
$$

It is easy to verify that $e(p)$ is increasing. The tenant's equilibrium payoff is $V(p)=v(0, \omega)+\frac{e(p)(1-p)}{p}$ which is larger than the payoff from being a landless laborer.

It is straightforward to calculate the impact of changes in $p$ on output and the tenant's payoff. An increase in $p$ will increase net-output since $e(p)$ is increasing. The effect on the tenant's payoff (and hence poverty) is given by:

$$
V^{\prime}(p)=e^{\prime}(p)\left(\frac{1-p}{p}\right)-e(p)\left(\frac{1}{p^{2}}\right) .
$$


The first term is positive - an increase in the eviction probability elicits higher effort and hence raises the tenant's rent. The second effect works in the opposite direction. For a given effort level, the tenant's rent is lower since he must be paid less now to prevent him from shirking. We are interested in cases where the tenant enjoys a more secure right to the land so that $p$ falls. In this case, the tenant will benefit from a tenancy reform that reduces the probability that he will be evicted if caught shirking if the elasticity of effort with respect to the probability of eviction $\left(e^{\prime}(p) p / e(p)\right)$ is less than $1 /(1-p)$. If tenants' rents increase from receiving higher tenure security, then this will lead them to reduce their labor supply to the market and we would predict that such a tightening of the labor market would lead to increased agricultural wages. ${ }^{24}$

This framework can be applied to the cases of abolition of intermediaries and tenancy reform. To include an intermediary in the analysis, we suppose that there are three parties to the agricultural contract: a tenant, landlord and an intermediary. We begin by making the strong assumption that intermediaries have a very strong bargaining position can make take-it-or-leave-it offers to the landlord and tenant. This is very much in line with the view that intermediaries captured the surplus from the land. In this world, the tenant will receive a payoff of $V(p)$, and the landlord will receive his reservation payoff which we denote by $v_{L}$. The intermediary receives the surplus $[R(e(p))-e(p)]-V(p)-v_{L}$.

After the intermediary is abolished, this surplus is now available for distribution provided that $p$ remains the same. Only if the tenant obtains no bargaining power at all with his landlord, would we expect to observe no effect on the tenant's pay-off. Otherwise, we would expect to see the tenant's payoff rise. Assuming that tenants are a significant group of poor in India, this is consistent with our finding that poverty is reduced by the abolition of intermediaries. We would not expect to see any change in effort and hence output unless $p$ were different when landlords and intermediaries negotiated contracts. Rent increases for tenants also would be associated with higher agricultural wages, by the general equilibrium mechanism we have identified.

We now turn to the impact of tenancy reforms. Such reforms are multifarious which make it difficult to offer a definitive theoretical account. This would require much more institutional content as in the analysis of West Bengal's land reforms by Banerjee and Ghatak (1997). Nonetheless, it is still useful to think through a simple model in order to check that our empirical findings conform to the pre-

\footnotetext{
${ }^{24}$ These changes in wages would also be expected to reinforce reductions in output on farms that hire in labor.
} 
dictions of the theory laid out above. Suppose therefore that the landlord has all the bargaining power and can make a take-it-or-leave-it offers to tenants before and after the tenancy reform. We shall model the effect of a tenancy reforms as making it more difficult to evict tenants if they shirk. In terms of our model this is equivalent to a fall in $p$. As we have already argued, this has two effects. First, we expect effort, and therefore, output to fall. Second, we expect a change in the payoff to the tenant as his rent could go up or down. We showed that this is positive under reasonable conditions and thus we would expect poverty to be reduced which is exactly what we found in our data. This is also consistent with when we would expect agricultural wages to rise since increased rents to tenancies tends to reduce their labor supply.

To summarize, the empirical findings are consistent with a stylized model of agricultural contracting and labor supply by tenants. While many complicating features could be added to the theory, the general thrust of the trade-off captured here is relevant. ${ }^{25}$ It is well known that in a variety of contexts, rents are used to motivate tenants. Thus, land reforms that affect how agency problems are solved will typically generate both output and distributional effects. It also seems plausible that these rents will affect labor supply and that this leads to changes in agricultural wages.

\section{Concluding Remarks}

The main contribution of this paper is to test whether land reform legislation is associated with poverty reductions using state level data from India. The high incidence of poverty and the large volume of land reforms enacted to counter this problem in the post-Independence period make this an issue of considerable interest from a public policy perspective. We show that there is robust evidence of a link between poverty reduction and two kinds of land reform legislation - tenancy reform and abolition of intermediaries. Another important finding is that land reform can benefit the landless by raising agricultural wages. Though the effects on poverty are likely to have been greater had large-scale redistribution of land been achieved, our results are nonetheless interesting as they suggest that partial, second best reforms which mainly affect production relations in agriculture can play a significant role in reducing rural poverty.

\footnotetext{
${ }^{25}$ Clearly a complete theoretical treatment would require a much more detailed analysis. Following Banerjee and Ghatak (1997), it would be possible to introduce investment into the model. They show when we would expect tenure security to increase investment incentives.
} 
As well as being important to policy debates in India, such findings may help to diffuse the more general pessimism that can undermine redistributive effort in developing countries. In a recent study (World Bank (1997)), much emphasis was placed on the role of economic growth in explaining the decline of poverty in India. While our results are consistent with this finding, they emphasise that redistributive effort has also played its part. Using the average number of land reforms implemented, our first coefficient in Table 3 implies that a reduction of the all-India poverty gap of $1 \%$ can be explained by land reform. This is one tenth of the actual reduction in poverty over the period of our data. This remains true even after factoring in the possibility that output per capita is reduced by some kinds of land reform (Table 8).

Since the effects of redistributive intervention on poverty and growth are not known a priori, a significant literature has tested these links using cross-country data. Benabou (1996) reviews this literature and emphasises the diverse findings. While adding to our general understanding, the difficulties of finding reliable cross-country measures of redistribution is a significant draw back in this research agenda. There seems little doubt, therefore, that exploiting policy variation due to the federal structure of some developing countries may be an important additional source of evidence on policy incidence. It will also help to get behind broad brush policy categories such as education or health expenditures that mask important policy variations. Our study underlines that, even within a particular area of government intervention (i.e. land reform), the empirical effects may vary depending on the exact form that the intervention takes. This is true, moreover, even though our policy measures are themselves fairly broad. Future efforts to quantify the empirical relationship between growth, poverty and redistribution will doubtless benefit even more from a detailed specification of how particular policy interventions are structured and implemented across space and time. 


\section{References}

[1] Alesina, A and Rodrik, D. (1994), 'Distributive Politics and Economic Growth', Quarterly Journal of Economics 109: 465-490.

[2] Appu, P.S. (1996), Land Reforms in India: A Survey of Policy Legislation and Implementation (New Delhi: Vikas)

[3] Bandyopadhyay, D. (1986), 'Land Reforms in India: An Analysis' Economic and Political Weekly, June 21-28.

[4] Banerjee, Abhijit and Maitreesh Ghatak, (1996), 'Empowerment and Efficiency: The Economics of Tenancy Reform' typescript MIT and University of Chicago.

[5] Banerjee, A. and Newman, A. (1993), 'Occupational Choice and the Process of Development', Journal of Political Economy 101: 659-684.

[6] Bardhan, Pranab, (1970), 'India,' in Chenery et al (eds) Redistribution with Growth, Oxford: Oxford University Press.

[7] Bardhan, Pranab (1990), The Economic Theory of Agrarian Institutions, Oxford: Oxford University Press.

[8] Benabou, R. (1996), 'Inequality and Growth', NBER Macroeconomics Annual.

[9] Binswanger, H., Deininger, K. and Feder, G. (1995), 'Power, Distortions, Revolt and Reform in Agricultural Land Relations' in Behrman, J. and Srinivasan, T.N. (ed) Handbook of Development Economics (Amsterdam: Elsevier).

[10] Chattopadhyay, S.N. (1992), 'Historical Context of Political Change in West Bengal: A Study of Seven Villages in Bardhaman' Economic and Political Weekly, March 28.

[11] Chenery, H. et al (1970), Redistribution with Growth (Oxford: Oxford University Press).

[12] Datt, Gaurav and Martin Ravallion, (1998), 'Why Have Some Indian States Done Better than Others at Reducing Poverty?', Economica, 65, 17-38. 
[13] Davidson, R. and McKinnon, J. (1993), Estimation and Inference in Econometrics (Oxford: Oxford University Press).

[14] Dreze, J. and Sen, A. (1995), India: Economic Development and Social Opportunity (Oxford: Clarendon Press)

[15] Dreze, J.P., Lanjouw, P. and Sharma, N. (1997), 'Economic Development 1957-1993' in Lanjouw, P. and Stern, N.H., A Kind of Growth: Palunpur 195\%-1993 (Oxford: Oxford University Press).

[16] Gough, K. (1987), 'Socio-Economic Change in Southeast India: 1950s to 1980s' Journal of Contemporary Asia, 17(3).

[17] Hoff. Karla, and Andrew B. Lyon, (1995), 'Non-leaky buckets: Optimal Redistributive Taxation and Agency Costs,' Journal of Public Economics, 58, 365-90.

[18] Jayaraman, R. and Lanjouw, P. (1997), 'Living Standards in Rural India: A Perspective from Longtitudinal Village Studies' mimeo Cornell University and World Bank.

[19] Mearns, R. (1998), 'Access to Land in Rural India: Policy Issues and Options' mimeo World Bank.

[20] Ozler, B. Datt, G. and Ravallion, M. (1996), 'A Data Base on Poverty and Growth in India' mimeo World Bank

[21] Persson, Torsten and Guido Tabellini, (1994), 'Is Inequality Harmful for Growth: Theory and Evidence,'American Economic Review 48, 600-621.

[22] Radhakrishnan, P. (1990), 'Land Reforms: Rhetoric and Reality' Economic and Political Weekly, November 24.

[23] Sargan, J. (1958), 'The Estimation of Economic Relationships Using Instrumental Variables' Econometrica 26, 393-415.

[24] Sharma, H.R. (1994), 'Distribution of Landholdings in Rural India, 195354 to 1981-1982: Implications for Land Reforms', Economic and Political Weekly, September 24

[25] Thorner, D. (1976), Agrarian Prospect in India (New Delhi: Allied Publishers). 
[26] Wadley, S.S. and Derr, B.W. (1990), 'Karimpur 1925-1984: Understanding Rural India through Restudies' in Bardhan, P. (ed) Conversations between Economists and Anthropologists (Delhi: Oxford University Press).

[27] Warriner, D. (1969), Land Reform in Priniciple and Practice (Oxford: Oxford University Press).

[28] World Bank (1997),'Poverty in India: 50 Years after Independence', World Bank mimeo. 
Table 1: Summary of Main Variables (s.d. in parethesis)

\begin{tabular}{|c|c|c|c|c|c|c|c|c|c|}
\hline state & $\begin{array}{l}\text { state } \\
\text { inc. } \\
\text { p.c }\end{array}$ & $\begin{array}{c}\text { inc } \\
\text { growth }\end{array}$ & $\begin{array}{c}\text { yield } \\
\text { (sdpag/ } \\
\text { nsa) }\end{array}$ & $\begin{array}{l}\text { head } \\
\text { count }\end{array}$ & $\begin{array}{l}\text { pov } \\
\text { gap }\end{array}$ & $\begin{array}{c}\text { agric } \\
\text { wages }\end{array}$ & $\begin{array}{l}\text { cum. } \\
\text { land } \\
\text { reform }\end{array}$ & $\begin{array}{l}\text { pop } \\
\text { grow }\end{array}$ & $\begin{array}{c}\text { prop } \\
\text { hard } \\
\text { left }\end{array}$ \\
\hline $\begin{array}{c}\text { Andra } \\
\text { Pradesh }\end{array}$ & $\begin{array}{l}1004 \\
(260)\end{array}$ & $\begin{array}{c}0.021 \\
(0.071)\end{array}$ & $\begin{array}{c}0.041 \\
(0.005)\end{array}$ & $\begin{array}{c}49.40 \\
(10.68)\end{array}$ & $\begin{array}{l}14.87 \\
(5.11)\end{array}$ & $\begin{array}{c}4.53 \\
(1.10)\end{array}$ & $\begin{array}{c}1.528 \\
(0.506)\end{array}$ & $\begin{array}{c}0.020 \\
(0.002)\end{array}$ & $\begin{array}{c}0.069 \\
(0.047)\end{array}$ \\
\hline Assam & $\begin{array}{c}903 \\
(196)\end{array}$ & $\begin{array}{c}0.026 \\
(0.071)\end{array}$ & $\begin{array}{c}0.152 \\
(0.017)\end{array}$ & $\begin{array}{l}46.73 \\
(8.77)\end{array}$ & $\begin{array}{l}10.69 \\
(2.67)\end{array}$ & $\begin{array}{c}5.35 \\
(1.04)\end{array}$ & $\begin{array}{c}2.000 \\
(1.069)\end{array}$ & $\begin{array}{c}0.025 \\
(0.004)\end{array}$ & $\begin{array}{c}0.046 \\
(0.042)\end{array}$ \\
\hline Bihar & $\begin{array}{c}633 \\
(110)\end{array}$ & $\begin{array}{c}0.007 \\
(0.102)\end{array}$ & $\begin{array}{c}0.037 \\
(0.005)\end{array}$ & $\begin{array}{l}63.25 \\
(6.17)\end{array}$ & $\begin{array}{l}20.88 \\
(4.67)\end{array}$ & $\begin{array}{c}4.07 \\
(1.01)\end{array}$ & $\begin{array}{c}4.305 \\
(1.924)\end{array}$ & $\begin{array}{c}0.020 \\
(0.001)\end{array}$ & $\begin{array}{c}0.068 \\
(0.031)\end{array}$ \\
\hline Gujarat & $\begin{array}{l}1176 \\
(272)\end{array}$ & $\begin{array}{c}0.019 \\
(0.135)\end{array}$ & $\begin{array}{c}0.044 \\
(0.008)\end{array}$ & $\begin{array}{l}52.36 \\
(9.13)\end{array}$ & $\begin{array}{l}15.81 \\
(4.94)\end{array}$ & $\begin{array}{c}4.39 \\
(0.78)\end{array}$ & $\begin{array}{c}3.056 \\
(1.264)\end{array}$ & $\begin{array}{c}0.023 \\
(0.003)\end{array}$ & 0 \\
\hline Haryana & $\begin{array}{l}1444 \\
(357)\end{array}$ & $\begin{array}{c}0.035 \\
(0.086)\end{array}$ & $\begin{array}{c}0.098 \\
(0.012)\end{array}$ & $\begin{array}{r}30.00 \\
(6.90)\end{array}$ & $\begin{array}{c}7.11 \\
(2.15)\end{array}$ & 0 & 0 & $\begin{array}{c}0.025 \\
(0.001)\end{array}$ & 0 \\
\hline $\begin{array}{l}\text { Jammu } \\
\text { Kashmir }\end{array}$ & $\begin{array}{l}1021 \\
(228)\end{array}$ & $\begin{array}{c}0.013 \\
(0.101)\end{array}$ & $\begin{array}{c}0.621 \\
(0.058)\end{array}$ & $\begin{array}{l}32.54 \\
(7.35)\end{array}$ & $\begin{array}{c}7.20 \\
(2.59)\end{array}$ & 0 & $\begin{array}{c}1.333 \\
(0.717)\end{array}$ & $\begin{array}{c}0.026 \\
(0.001)\end{array}$ & 0 \\
\hline Karnataka & $\begin{array}{l}1037 \\
(216)\end{array}$ & $\begin{array}{c}0.018 \\
(0.066)\end{array}$ & $\begin{array}{c}0.045 \\
(0.004)\end{array}$ & $\begin{array}{l}52.66 \\
(7.82)\end{array}$ & $\begin{array}{l}16.99 \\
(3.86)\end{array}$ & $\begin{array}{c}3.85 \\
(0.66)\end{array}$ & $\begin{array}{c}2.833 \\
(1.384)\end{array}$ & $\begin{array}{c}0.021 \\
(0.002)\end{array}$ & $\begin{array}{c}0.014 \\
(0.007)\end{array}$ \\
\hline Kerala & $\begin{array}{c}864 \\
(182)\end{array}$ & $\begin{array}{c}0.019 \\
(0.063)\end{array}$ & $\begin{array}{c}0.160 \\
(0.017)\end{array}$ & $\begin{array}{c}56.59 \\
(13.88)\end{array}$ & $\begin{array}{l}19.70 \\
(7.98)\end{array}$ & $\begin{array}{c}6.24 \\
(1.56)\end{array}$ & $\begin{array}{c}5.444 \\
(3.376)\end{array}$ & $\begin{array}{c}0.018 \\
(0.004)\end{array}$ & $\begin{array}{c}0.337 \\
(0.135)\end{array}$ \\
\hline $\begin{array}{l}\text { Madhya } \\
\text { Pradesh }\end{array}$ & $\begin{array}{c}843 \\
(190)\end{array}$ & $\begin{array}{c}0.013 \\
(0.106)\end{array}$ & $\begin{array}{c}0.022 \\
(0.003)\end{array}$ & $\begin{array}{l}56.14 \\
(7.08)\end{array}$ & $\begin{array}{r}18.03 \\
(4.11)\end{array}$ & $\begin{array}{c}3.81 \\
(0.83)\end{array}$ & $\begin{array}{c}2.806 \\
(0.710)\end{array}$ & $\begin{array}{c}0.024 \\
(0.001)\end{array}$ & 0 \\
\hline $\begin{array}{c}\text { Maharash } \\
\text { tra }\end{array}$ & $\begin{array}{l}1288 \\
(331)\end{array}$ & $\begin{array}{l}0.019 \\
(0.70)\end{array}$ & $\begin{array}{c}0.018 \\
(0.002)\end{array}$ & $\begin{array}{l}57.30 \\
(7.45)\end{array}$ & $\begin{array}{l}19.71 \\
(4.38)\end{array}$ & $\begin{array}{c}3.55 \\
(0.71)\end{array}$ & $\begin{array}{c}1.861 \\
(0.424)\end{array}$ & $\begin{array}{c}0.023 \\
(0.001)\end{array}$ & $\begin{array}{c}0.078 \\
(0.038)\end{array}$ \\
\hline Orissa & $\begin{array}{c}873 \\
(186)\end{array}$ & $\begin{array}{c}0.015 \\
(0.128)\end{array}$ & $\begin{array}{c}0.070 \\
(0.014)\end{array}$ & $\begin{array}{l}56.55 \\
(9.04)\end{array}$ & $\begin{array}{l}17.42 \\
(4.62)\end{array}$ & $\begin{array}{c}4.07 \\
(0.85)\end{array}$ & $\begin{array}{c}5.056 \\
(3.116)\end{array}$ & $\begin{array}{c}0.019 \\
(0.002)\end{array}$ & $\begin{array}{c}0.036 \\
(0.021)\end{array}$ \\
\hline Punjab & $\begin{array}{l}1732 \\
(334)\end{array}$ & $\begin{array}{c}0.031 \\
(0.060)\end{array}$ & $\begin{array}{c}0.113 \\
(0.014)\end{array}$ & $\begin{array}{l}24.67 \\
(8.48)\end{array}$ & $\begin{array}{c}5.54 \\
(2.90)\end{array}$ & $\begin{array}{c}8.16 \\
(1.09)\end{array}$ & $\begin{array}{c}0.75 \\
(0.44)\end{array}$ & $\begin{array}{c}0.020 \\
(0.001)\end{array}$ & $\begin{array}{c}0.093 \\
(0.033)\end{array}$ \\
\hline Rajasthan & $\begin{array}{c}785 \\
(136)\end{array}$ & $\begin{array}{c}0.014 \\
(0.144)\end{array}$ & $\begin{array}{c}0.027 \\
(0.003)\end{array}$ & $\begin{array}{l}51.37 \\
(7.37)\end{array}$ & $\begin{array}{l}16.96 \\
(3.81)\end{array}$ & $\begin{array}{c}5.12 \\
(0.68)\end{array}$ & $\begin{array}{c}0.944 \\
(0.232)\end{array}$ & $\begin{array}{c}0.026 \\
(0.002)\end{array}$ & $\begin{array}{c}0.011 \\
(0.010)\end{array}$ \\
\hline $\begin{array}{l}\text { Tamil } \\
\text { Nadu }\end{array}$ & $\begin{array}{l}1015 \\
(272)\end{array}$ & $\begin{array}{c}0.020 \\
(0.101)\end{array}$ & $\begin{array}{c}0.052 \\
(0.008)\end{array}$ & $\begin{array}{l}54.45 \\
(7.84)\end{array}$ & $\begin{array}{l}18.58 \\
(4.40)\end{array}$ & $\begin{array}{c}3.92 \\
(0.52)\end{array}$ & $\begin{array}{c}4.917 \\
(2.545)\end{array}$ & $\begin{array}{c}0.016 \\
(0.003)\end{array}$ & $\begin{array}{c}0.042 \\
(0.027)\end{array}$ \\
\hline $\begin{array}{c}\text { Uttar } \\
\text { Pradesh }\end{array}$ & $\begin{array}{c}874 \\
(140)\end{array}$ & $\begin{array}{c}0.011 \\
(0.081)\end{array}$ & $\begin{array}{c}0.025 \\
(0.002)\end{array}$ & $\begin{array}{l}47.86 \\
(7.20)\end{array}$ & $\begin{array}{l}12.84 \\
(3.14)\end{array}$ & $\begin{array}{c}4.71 \\
(1.38)\end{array}$ & $\begin{array}{c}3.750 \\
(1.251)\end{array}$ & $\begin{array}{c}0.021 \\
(0.003)\end{array}$ & $\begin{array}{c}0.023 \\
(0.009)\end{array}$ \\
\hline $\begin{array}{c}\text { West } \\
\text { Bengal }\end{array}$ & $\begin{array}{l}1173 \\
(191)\end{array}$ & $\begin{array}{c}0.011 \\
(0.064)\end{array}$ & $\begin{array}{c}0.074 \\
(0.007)\end{array}$ & $\begin{array}{c}46.88 \\
(10.31)\end{array}$ & $\begin{array}{l}14.92 \\
(5.32)\end{array}$ & $\begin{array}{c}6.12 \\
(1.81)\end{array}$ & $\begin{array}{c}6.139 \\
(5.581)\end{array}$ & $\begin{array}{c}0.023 \\
(0.002)\end{array}$ & $\begin{array}{c}0.455 \\
(0.256)\end{array}$ \\
\hline TOTAL & $\begin{array}{l}1078 \\
(556)\end{array}$ & $\begin{array}{c}0.017 \\
(0.094)\end{array}$ & $\begin{array}{c}0.098 \\
(0.141)\end{array}$ & $\begin{array}{c}49.16 \\
(13.07)\end{array}$ & $\begin{array}{r}15.10 \\
(6.27)\end{array}$ & $\begin{array}{c}4.799 \\
(1.584)\end{array}$ & $\begin{array}{c}2.910 \\
(2.749)\end{array}$ & $\begin{array}{c}0.022 \\
(0.003)\end{array}$ & $\begin{array}{c}0.078 \\
(0.142)\end{array}$ \\
\hline
\end{tabular}




\section{Table 2: Important Events in Land Reforms in Indian States since 1950}

\begin{tabular}{|c|c|c|c|c|}
\hline State & Year & Title & Description & Class. \\
\hline Andhra Pradesh & $\begin{array}{l}1952 \\
1954 \\
1955 \\
\\
1956 \\
1956 \\
(\text { am. } 74) \\
\\
1957\end{array}$ & $\begin{array}{l}\text { (Telengana Area) } \\
\text { Tenancy and } \\
\text { Agricultural Lands Act } \\
\text { Hyderabad Abolition } \\
\text { of Cash Grants Act } \\
\text { Inams Abolition Act } \\
\text { (Absorbed) Enclaves } \\
\text { (Hyderabad Jagirdars) } \\
\text { Act } \\
\text { Inam (Abolition and } \\
\text { Conversion into } \\
\text { Ryotwari) Act } \\
\text { Tenancy Act } \\
\end{array}$ & $\begin{array}{l}\text { (Inter alia) Tenants received protected tenancy } \\
\text { status; tenants to have minimum term of lease; } \\
\text { right of purchase of non-resumable lands; } \\
\text { transfer of ownership to protected tenants in } \\
\text { respect of non-resumable lands; as a result } 13611 \\
\text { protected tenants declared owners. } \\
\text { Abolition of all the } 975 \text { jagirs in Talangena. } \\
\text { Abolition of inams (with few exceptions). } \\
\text { Abolition of all the } 975 \text { jagirs in Talangena. } \\
\text { Acquisition of } 11137 \text { estates; abolition of } 1.06 \\
\text { million minor inams. (CHECK!) } \\
\text { Tenancy continues upto } 2 / 3 \text { of ceiling area; law } \\
\text { does not provide for conferment of ownership } \\
\text { right on tenants except through right to purchase; } \\
\text { confers continuous right of resumption on } \\
\text { landowners. } \\
\text { Abolition of inams (with few exceptions), struck } \\
\text { down by the High Court in } 1970 .\end{array}$ & $\begin{array}{l}2 \\
2 \\
2\end{array}$ \\
\hline Assam & $\begin{array}{l}1951 \\
1954 \\
\\
1956 \\
\left(\begin{array}{l}\text { am. } 76) \\
1960 \\
1971\end{array}\right. \\
\end{array}$ & $\begin{array}{l}\text { State Acquisition of } \\
\text { Zamindari Act } \\
\text { Lushai Hills District } \\
\text { (Acquisition of Chiefs } \\
\text { Rights) Act } \\
\text { Fixation of Ceiling on } \\
\text { Land Holdings Act } \\
\text { Consolidation of } \\
\text { Holdings Act } \\
\text { (Temporarily Settled } \\
\text { Areas) Tenancy Act }\end{array}$ & $\begin{array}{l}\text { Abolition of intermediary rights involving } 0.67 \\
\text { million hectares. } \\
\text { Same as above. } \\
\text { Self-explanatory. } \\
\text { Introduction of compulsory consolidation. } \\
\text { Classifies tenants into occupancy and non- } \\
\text { occupancy tenants; former has security of tenure, } \\
\text { may acquire landlord's right of holding by paying } \\
50 \text { times the land revenue; subletting is } \\
\text { disallowed. }\end{array}$ & $\begin{array}{l}3 \\
4 \\
1\end{array}$ \\
\hline
\end{tabular}




\begin{tabular}{|c|c|c|c|c|}
\hline Bihar & 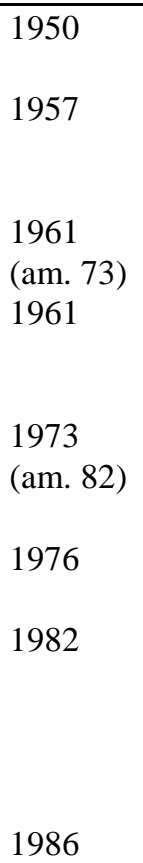 & $\begin{array}{l}\text { Land Reforms Act } \\
\text { Homestead Tenancy } \\
\text { Act } \\
\text { Land Reforms Act } \\
\text { Land Ceiling Act } \\
\text { Act } 12 \text { (amendment to } \\
\text { Land Reforms Act) } \\
\text { Act } 55 \\
\text { Tenancy (Amendment) } \\
\text { Act }\end{array}$ & $\begin{array}{l}\text { Abolition of zamindari; implementation of this } \\
\text { act very slow. } \\
\text { Confers rights of permanent tenancy in } \\
\text { homestead lands on persons holding less than } \\
\text { one acre of land. } \\
\text { Prohibits subletting, preventing sub-lessee from } \\
\text { acquiring right of occupancy. } \\
\text { Imposition of ceiling on landholdings of } 9.71- \\
29.14 \text { hectares (1960-1972) and of } 6.07-18.21 \\
\text { hectare (after 1972). } \\
\text { Introduced provisions relating to the voluntary } \\
\text { surrender of surplus land. } \\
\text { (Inter alia) Provided for the substitution of legal } \\
\text { heir; ceiling area shall be redetermined when } \\
\text { classification of land changes; ordered that the } \\
\text { landholder necessarily retain land transferred in } \\
\text { contravention of the Act. } \\
\text { Provides definition of personal cultivation; } \\
\text { provides for acquisition of occupancy rights by } \\
\text { underraiyats. }\end{array}$ & $\begin{array}{l}3 \\
3\end{array}$ \\
\hline Gujarat & $\begin{array}{l}\begin{array}{l}1948 \\
(\mathrm{am} .55 \\
\& 60)\end{array} \\
1960 \\
1969 \\
1973\end{array}$ & $\begin{array}{l}\text { Bombay Tenancy and } \\
\text { Agricultural Lands Act } \\
\text { Agricultural Lands } \\
\text { Ceiling Act } \\
\text { Devasthan Inam } \\
\text { Abolition Act } \\
\text { Amending Act }\end{array}$ & $\begin{array}{l}\text { Tenants entitled to acquire right of ownership } \\
\text { after expiry of one year upto ceiling area; confers } \\
\text { ownership right on tenants in possession of } \\
\text { dwelling site on payment of } 20 \text { times annual rent; } \\
\text { law does not confer any rights on sub-tenants. } \\
\text { Imposed ceiling on landholdings of } 4.05-53.14 \\
\text { hectares (1960-1972) and of } 4.05-21.85 \text { hectares } \\
\text { (after 1972). } \\
\text { Abolishes all grades of intermediary tenures, but } \\
\text { law was partially injuncted from implementation } \\
\text { by order of Supreme Court. } \\
\text { Provides opportunity to acquire ownership of } \\
\text { holdings but largely overridden by numerous } \\
\text { provisions. }\end{array}$ & 2 \\
\hline Haryana & 1953 & $\begin{array}{l}\text { Punjab Security of } \\
\text { Land Tenures Act } \\
\text { Pepsu Tenancy and } \\
\text { Agricultural Land Act }\end{array}$ & $\begin{array}{l}\text { Provides complete security of tenure for tenants } \\
\text { in continuous possession of land ( }<15 \text { acres) for } \\
12 \text { years; grants tenants optional right of } \\
\text { purchase of ownership of non-resumable land; no } \\
\text { bar on future leasing. } \\
\text { Same as above. }\end{array}$ & 1 \\
\hline Jammu \& Kashmir & $\begin{array}{l}1962 \\
1976\end{array}$ & Agrarian Reforms Act & $\begin{array}{l}\text { Introduction of compulsory consolidation. } \\
\text { All rights, titles, and interests in land of any } \\
\text { person not cultivating it personally in kharif } \\
1971 \text { are extinguished and transferred to the } \\
\text { state; provides for conferment of ownership } \\
\text { rights on tenants after allowing resident landlord } \\
\text { to resume land for personal cultivation. }\end{array}$ & $\begin{array}{l}4 \\
1\end{array}$ \\
\hline
\end{tabular}




\begin{tabular}{|c|c|c|c|c|}
\hline Karnataka & $\begin{array}{l}1954 \\
1955 \\
1961 \\
(\text { effect. } \\
65) \\
\\
1974\end{array}$ & $\begin{array}{l}\text { Mysore (Personal and } \\
\text { Miscellaneous) Inam } \\
\text { Abolition Act } \\
\text { Mysore (Religious and } \\
\text { Charitable) Inams } \\
\text { Abolition Act } \\
\text { Land Reforms Act } \\
\\
\text { Land Reforms } \\
\text { (Amendment) Act }\end{array}$ & $\begin{array}{l}\text { Abolished all the large inamdari intermediaries; } \\
\text { process of implementation very slow. } \\
\text { Same as above. } \\
\text { Provides for fixity of tenure subject to landlord's } \\
\text { right to resume } 1 / 2 \text { leased area; grants tenants } \\
\text { optional right to purchase ownership on payment } \\
\text { of } 15-20 \text { times the net rent; imposition of ceiling } \\
\text { on landholdings. } \\
\text { Imposition of ceiling on landholdings of } 4.05- \\
21.85 \text { hectares (after } 1972 \text { ); removal of all but } \\
\text { one of the exemptions from tenancy legislation. }\end{array}$ & 1,3 \\
\hline Kerala & $\begin{array}{l}1960 \\
1963 \\
1969 \\
(\text { effect. } \\
70) \text { am. } \\
79 \\
\\
1974\end{array}$ & $\begin{array}{l}\text { Agrarian Relations Act } \\
\text { Land Reforms Act } \\
\text { Land Reforms } \\
\text { (Amendment) Act }\end{array}$ & $\begin{array}{l}\text { Abolishes intermediaries, but law struck down by } \\
\text { Supreme Court. } \\
\text { Concedes tenant's right to purchase the land from } \\
\text { landowners. } \\
\text { Conferment of full ownership rights on tenants; } \\
2.5 \text { million tenants could become landowners; } \\
\text { right of resumption expires; although far- } \\
\text { reaching on paper, law "not conducive to social } \\
\text { justice" because of concealed tenancy; } \\
\text { imposition of ceiling on landholdings of } \\
6.07-15.18 \text { hectares (1960-1972) and of } 4.86- \\
6.07 \text { hectares (after 1972); abolition of } \\
\text { intermediary rights. } \\
\text { Called for employment security, fixed hours, } \\
\text { minimum wages, etc. }\end{array}$ & $\begin{array}{l}2 \\
1 \\
1,2,3\end{array}$ \\
\hline Madhya Pradesh & $\begin{array}{l}1951 \\
1952 \\
\\
1959\end{array}$ & $\begin{array}{l}\text { Abolition of } \\
\text { Proprietary Rights } \\
\text { (Estates, Mahals, } \\
\text { Alienated Lands) Act } \\
\text { United States of } \\
\text { Gwalior, Indore and } \\
\text { Malwa Zamindari } \\
\text { Abolition Act } \\
\text { Abolition of Jagir Act } \\
\text { Vindhya Pradesh } \\
\text { Abolition of Jagirs and } \\
\text { Land Reforms Act } \\
\text { Land Revenue Code } \\
\\
\text { Ceiling on Agricultural } \\
\text { Holdins Act }\end{array}$ & $\begin{array}{l}\text { Same as above. } \\
\text { Same as above. } \\
\text { Same as above. } \\
\text { Leasing prohibited; entitles occupancy tenants to } \\
\text { owner ship rights of non-resumable area on } \\
\text { payment of } 15 \text { times the land revenue; } \\
\text { implementation of reform inefficient, one reason } \\
\text { being that sharecroppers and tenants are not } \\
\text { recorded. } \\
\text { Introduction of compulsory consolidation. } \\
\text { Imposed ceiling on landholdings of } 10.12 \\
\text { hectares (1960-1972) and of } 4.05-21.85 \text { hectares } \\
\text { (after 1972). }\end{array}$ & $\begin{array}{l}4 \\
3\end{array}$ \\
\hline
\end{tabular}




\begin{tabular}{|c|c|c|c|c|}
\hline Maharashtra & $\begin{array}{l}1950 \\
1958 \\
1961\end{array}$ & $\begin{array}{l}\text { Hyderabad Tenancy } \\
\text { and Agricultural Lands } \\
\text { Act } \\
\text { Bombay Tenancy and } \\
\text { Agricultural Land Act } \\
\text { Agricultural Land } \\
\text { (Ceiling on Holdings) } \\
\text { Act }\end{array}$ & $\begin{array}{l}\text { Provides for suo motto transfer of ownership to } \\
\text { tenants of non-resumable lands (applies to } \\
\text { Marathawada region). } \\
\text { Provides for transfer of ownership to tenants } \\
\text { with non-resumable lands (with effect from } \\
\text { 1-4-96). } \\
\text { Imposition of ceiling on landholdings. }\end{array}$ & 1 \\
\hline Orissa & $\begin{array}{l}1951 \\
1972 \\
1960 \\
(\mathrm{am} .73 \\
\& 76) \\
\\
\\
\end{array}$ & $\begin{array}{l}\text { Estate Abolition Act } \\
\text { Land Reforms Act } \\
\text { Land Reforms Act }\end{array}$ & $\begin{array}{l}\text { Aimed at abolishing all intermediary interests. } \\
\text { Entitled tenants to acquire ryoti rights over entire } \\
\text { land held by them. } \\
\text { Provides for fixity of tenure of non-resumable } \\
\text { area; prohibits subletting; implementation poor; } \\
\text { financial help for purchase of ownership right } \\
\text { lacking; most leases in form of sharecropping but } \\
\text { sharecroppers not recorded as tenants; } \\
\text { imposition of ceiling on landholdings of } \\
8.09-32.37 \text { hectares (1960-1972) and of } 4.05- \\
\text { 18.21 hectares (after 1972). } \\
\text { Introduction of compulsory consolidation. }\end{array}$ & $\begin{array}{l}2 \\
2 \\
1,3\end{array}$ \\
\hline Punjab & $\begin{array}{l}1953 \\
1955 \\
1972\end{array}$ & $\begin{array}{l}\text { Punjab Security of } \\
\text { Land Tenures Act } \\
\text { Pepsu Tenancy and } \\
\text { Agricultural Land Act } \\
\text { Land Reforms Act }\end{array}$ & $\begin{array}{l}\text { See under Haryana. } \\
\text { See under Haryana. } \\
\text { Permissible limit (ceiling) is } 7 \text { hectares; } 5 \text { acres } \\
\text { of land are secured, the rest may be resumed; } \\
\text { optional right of purchase of ownership; } \\
\text { sharecropping not considered tenancy; tenants } \\
\text { often coerced to "voluntarily surrender" land; } \\
\text { land leases not registered under provision of } \\
\text { tenancy laws. }\end{array}$ & $\begin{array}{l}1 \\
1 \\
1\end{array}$ \\
\hline Rajasthan & $\begin{array}{l}1952 \\
1953 \\
1953 \\
1955 \\
1955 \\
1959\end{array}$ & $\begin{array}{l}\text { Land Reforms and } \\
\text { Resumption of Jagir } \\
\text { Act } \\
\text { Bombay Merged } \\
\text { Territories and Area } \\
\text { (Jagir Abolition) Act } \\
\text { ??? } \\
\text { Ajmer Abolition of } \\
\text { Intermediaries and } \\
\text { Land Reforms Act } \\
\text { Tenancy Act } \\
\\
\text { Zamindari and } \\
\text { Biswedari Abolition } \\
\text { Act }\end{array}$ & $\begin{array}{l}\text { Abolishes all intermediary rights. } \\
\text { Same as above. } \\
\text { Introduction of compulsory consolidation. } \\
\text { Abolishes intermediary interests in other areas. } \\
\text { Confers security of tenure to tenants and sub- } \\
\text { tenants; ownership rights can be transferred; } \\
\text { provisions of voluntary surrender made legis- } \\
\text { lation "mere farce." } \\
\text { Abolishes intermediary interests in other areas. }\end{array}$ & $\begin{array}{l}4 \\
2\end{array}$ \\
\hline
\end{tabular}




\begin{tabular}{|c|c|c|c|c|}
\hline Tamil Nadu & $\begin{array}{l}1948 \\
1952 \\
1955 \\
(\mathrm{am} .65) \\
1956 \\
1961 \\
(\mathrm{am} .71) \\
1961 \\
1969 \\
1976\end{array}$ & $\begin{array}{l}\text { Estates (Abolition and } \\
\text { Conversion into } \\
\text { Ryotwari) Act XXVI } \\
\text { Thanjavur Tenants and } \\
\text { Pannaiyal Protection } \\
\text { Act } \\
\text { Madras Cultivating } \\
\text { Tenants Protection Act } \\
\text { Cultivating Tenants } \\
\text { (Payment of Fair Rent) } \\
\text { Act } \\
\text { Public Tenants Act } \\
\text { Land Reforms } \\
\text { (Fixation of Ceiling on } \\
\text { Land) Act } \\
\text { Agricultural Land- } \\
\text { Records of Tenancy } \\
\text { Right Act } \\
\text { Occupants of } \\
\text { Kudiyiruppu Act } \\
\text { Rural Artisans } \\
\text { (Conferment of } \\
\text { Ownership of } \\
\text { Kudiyiruppu) Act }\end{array}$ & $\begin{array}{l}\text { A series of laws enacted (through long intervals) } \\
\text { for the abolition of various types of } \\
\text { intermediaries. } \\
\text { Prohibits any cultivating tenant from being } \\
\text { evicted but allows for resumption upto } 1 / 2 \text { of } \\
\text { lands leased out to tenant. } \\
\text { Abolishes usury and rack-renting. } \\
\text { Provides that no public trust can evict its } \\
\text { cultivating tenants. } \\
\text { Imposition of ceiling on landholdings of } \\
\text { 12.14-48.56 hectares (1960-1972) and of } 4.86- \\
24.28 \text { hectares (after 1972). } \\
\text { Provides for preparation and maintenance of } \\
\text { complete record of tenancy rights. } \\
\text { Provides for acquisition and conferment of } \\
\text { ownership rightson agriculturists, agricultural } \\
\text { laborers and rural artisans. } \\
\text { Same as above. }\end{array}$ & $\begin{array}{l}1 \\
3\end{array}$ \\
\hline Uttar Pradesh & $\begin{array}{l}1953 \\
1960 \\
\text { (effect. } \\
61)\end{array}$ & $\begin{array}{l}\text { Consolidation of } \\
\text { Holdings Act } \\
\text { Imposition of Ceilings } \\
\text { on Landholdings Act }\end{array}$ & $\begin{array}{l}\text { All tenants are given complete security of tenure } \\
\text { without any right of resumption for the } \\
\text { landowner; leases, in general, are banned; law } \\
\text { provided for transferring and vesting of of all } \\
\text { zamindari estates; zamindari was abolished over } \\
60.2 \text { million acres (out of total state area of } 72.6 \\
\text { million acres). } \\
\text { Introduction of compulsory consolidation. } \\
\text { Imposition of ceiling on landholdings of } 16.19 \text { - } \\
32.37 \text { hectares (1960-1972) and of 7.30-18.25 } \\
\text { hectares (after 1972). }\end{array}$ & $\begin{array}{l}4 \\
3\end{array}$ \\
\hline
\end{tabular}




\begin{tabular}{|c|c|c|c|c|}
\hline West Bengal & $\begin{array}{l}1950 \\
1953 \\
1955(\mathrm{am} \\
70,71 \& \\
77) \\
1972 \\
1975\end{array}$ & $\begin{array}{l}\text { Acquisition and } \\
\text { Settlement of } \\
\text { Homestead Land } \\
\text { (Amendment) Act } \\
\text { Acquisition of } \\
\text { Homestead Land for } \\
\text { Agricultural Laborers, } \\
\text { Artisans and } \\
\text { Fishermen Act } \\
\text { Land Reforms } \\
\text { (Amendment) Act } \\
\text { Land Reforms } \\
\text { (Amendment) Act } \\
\text { Land Reforms } \\
\text { (Amendment) Act } \\
\\
\text { Land Reforms } \\
\text { (Amendment) Act }\end{array}$ & $\begin{array}{l}\text { Stipulated that the bargadar and the landowner } \\
\text { could choose any proportion acceptable to them. } \\
\text { Landholders limited to a ceiling; provided for } \\
\text { abolition of all intermediary tenures } \\
\text { Provides that landowner can resume land for } \\
\text { personal cultivation such that tenant is left with } \\
\text { at least } 1 \text { hectare; sharecropping not considered } \\
\text { tenancy (in West Bengal most tenants are } \\
\text { sharecroppers); provides for land consolidation if } \\
\text { two or more landowners agree. } \\
\text { Tenants of homestead lands are given full rights. } \\
\text { Over } 2.5 \text { lakh persons were given homestead } \\
\text { land (about eight cents each) up to Jan } 1991 . \\
\text { "Raises presumption in favor of sharecroppers" } \\
\text { (Yugandhar \& Iyer, p. 48) } \\
\text { Designed to plug the loopholes in the earlier } \\
\text { Acts relating to the ceiling of landholdings. } \\
\text { Sought to bring all classes of land under the } \\
\text { ceiling provisions by withdrawing previous } \\
\text { exemptions; provided for regulatory measures to } \\
\text { check indiscriminate conversion of land from } \\
\text { one use to another; law not yet fully } \\
\text { implemented. } \\
\text { Same as above. }\end{array}$ & $\begin{array}{l}1 \\
1,2 \\
1,4\end{array}$ \\
\hline
\end{tabular}

Classification Codes:

\section{Tenancy Reforms}

2. Abolition of Intermediaries

3. Ceilings on Landholdings

4. Consolidation of Land Holdings 
Table 3: Land Reform and Poverty in India: Basic Results (z statistics in parenthesis) ${ }^{1}$

\begin{tabular}{|c|c|c|c|c|c|c|c|c|}
\hline & $\begin{array}{c}\text { rural } \\
\text { pov } \\
\text { gap } \\
(1) \\
\end{array}$ & $\begin{array}{l}\text { rural } \\
\text { pov } \\
\text { gap } \\
(2) \\
\end{array}$ & $\begin{array}{l}\text { rural } \\
\text { pov } \\
\text { gap } \\
(3) \\
\end{array}$ & $\begin{array}{c}\text { rural } \\
\text { head } \\
\text { count } \\
(4)\end{array}$ & $\begin{array}{c}\text { urban } \\
\text { pov } \\
\text { gap } \\
(5)\end{array}$ & $\begin{array}{c}\mathrm{PG}_{\mathrm{R}} \\
-\mathrm{PG}_{\mathrm{U}} \\
\\
(6) \\
\end{array}$ & $\begin{array}{c}\mathrm{PG}_{\mathrm{R}} \\
-\mathrm{PG}_{\mathrm{U}} \\
\\
\\
(7) \\
\end{array}$ & $\begin{array}{c}\mathrm{HC}_{\mathrm{R}} \\
-\mathrm{HC}_{\mathrm{U}} \\
(8)\end{array}$ \\
\hline model & $\begin{array}{c}\text { GLS } \\
\text { AR(1) }\end{array}$ & $\begin{array}{c}\text { GLS } \\
\operatorname{AR}(1)\end{array}$ & $\begin{array}{c}\text { GLS } \\
\operatorname{AR}(1)\end{array}$ & $\begin{array}{c}\text { GLS } \\
\operatorname{AR}(1)\end{array}$ & $\begin{array}{c}\text { GLS } \\
\operatorname{AR}(1)\end{array}$ & $\begin{array}{c}\text { GLS } \\
\text { AR(1) }\end{array}$ & $\begin{array}{c}\text { GLS } \\
\operatorname{AR}(1)\end{array}$ & $\begin{array}{c}\text { GLS } \\
\operatorname{AR}(1)\end{array}$ \\
\hline $\begin{array}{l}\text { lagged (t-4) } \\
\text { cumulative } \\
\text { land reform }\end{array}$ & $\begin{array}{l}-0.281 \\
(2.18)\end{array}$ & $\begin{array}{c}-0.443 \\
(3.21)\end{array}$ & & & $\begin{array}{l}0.085 \\
(1.05)\end{array}$ & $\begin{array}{c}-0.534 \\
(5.24)\end{array}$ & & \\
\hline $\begin{array}{l}\text { lagged }(\mathrm{t}-4) \\
\text { tenancy reforms }\end{array}$ & & & $\begin{array}{r}-0.604 \\
(2.52)\end{array}$ & $\begin{array}{l}-1.378 \\
(3.13)\end{array}$ & & & $\begin{array}{l}-0.736 \\
(3.27)\end{array}$ & $\begin{array}{l}-1.916 \\
(4.37)\end{array}$ \\
\hline $\begin{array}{c}\text { lagged (t-4) } \\
\text { abolition inter }\end{array}$ & & & $\begin{array}{l}-2.165 \\
(4.08)\end{array}$ & $\begin{array}{l}-4.354 \\
(4.11)\end{array}$ & & & $\begin{array}{l}-1.327 \\
(2.59)\end{array}$ & $\begin{array}{l}-3.364 \\
(3.73)\end{array}$ \\
\hline $\begin{array}{l}\text { lagged }(\mathrm{t}-4) \\
\text { land cielings }\end{array}$ & & & $\begin{array}{l}0.089 \\
(0.11)\end{array}$ & $\begin{array}{l}0.734 \\
(0.86)\end{array}$ & & & $\begin{array}{l}0.230 \\
(0.61)\end{array}$ & $\begin{array}{l}0.888 \\
(1.14)\end{array}$ \\
\hline $\begin{array}{c}\text { lagged }(\mathrm{t}-4) \\
\text { consolidation land }\end{array}$ & & & $\begin{array}{l}0.456 \\
(0.82)\end{array}$ & $\begin{array}{l}-0.208 \\
(0.19)\end{array}$ & & & $\begin{array}{l}-0.210 \\
(0.42)\end{array}$ & $\begin{array}{l}-1.737 \\
(1.62)\end{array}$ \\
\hline state effects & YES & YES & YES & YES & YES & YES & YES & YES \\
\hline year effects & YES & YES & YES & YES & YES & YES & YES & YES \\
\hline $\begin{array}{l}\text { no. } \\
\text { obs. }\end{array}$ & 506 & 300 & 506 & 506 & 507 & 507 & 507 & 507 \\
\hline
\end{tabular}

${ }^{1}$ All regressions are reported with robust standard errors. 
Table 4: Land Reform and Poverty in India: Controlling for Omitted Policy Effects ( $\mathrm{z}$ statistics in parenthesis) $^{2}$

\begin{tabular}{|c|c|c|c|c|c|c|}
\hline & $\begin{array}{l}\text { rural } \\
\text { pov } \\
\text { gap } \\
(1) \\
\end{array}$ & $\begin{array}{c}\text { rural } \\
\text { poverty } \\
\text { gap } \\
(2)\end{array}$ & $\begin{array}{l}\text { rural } \\
\text { head } \\
\text { count } \\
(3) \\
\end{array}$ & $\begin{array}{c}\text { urban } \\
\text { poverty } \\
\text { gap } \\
(4)\end{array}$ & $\begin{array}{l}\mathrm{PG}_{\mathrm{R}} \\
-\mathrm{PG}_{\mathrm{U}} \\
\\
\\
(5) \\
\end{array}$ & $\begin{array}{r}\mathrm{HC}_{\mathrm{R}} \\
-\mathrm{HC}_{\mathrm{U}} \\
\\
(6) \\
\end{array}$ \\
\hline & $\begin{array}{c}\text { GLS } \\
\operatorname{AR}(1)\end{array}$ & $\begin{array}{c}\text { GLS } \\
\text { AR(1) }\end{array}$ & $\begin{array}{c}\text { GLS } \\
\operatorname{AR}(1)\end{array}$ & $\begin{array}{c}\text { GLS } \\
\text { AR(1) }\end{array}$ & $\begin{array}{c}\text { GLS } \\
\text { AR(1) }\end{array}$ & $\begin{array}{c}\text { GLS } \\
\operatorname{AR}(1)\end{array}$ \\
\hline $\begin{array}{l}\text { lagged }(\mathrm{t}-4) \\
\text { cumulative } \\
\text { land reform }\end{array}$ & $\begin{array}{l}-0.295 \\
(3.22)\end{array}$ & & & $\begin{array}{l}0.0004 \\
(0.005)\end{array}$ & $\begin{array}{l}-0.413 \\
(3.89)\end{array}$ & $\begin{array}{r}-1.136 \\
(4.77)\end{array}$ \\
\hline $\begin{array}{l}\text { lagged (t-4) } \\
\text { tenancy reforms }\end{array}$ & & $\begin{array}{l}-0.507 \\
(2.10)\end{array}$ & $\begin{array}{l}-0.937 \\
(2.00)\end{array}$ & & & \\
\hline $\begin{array}{l}\text { lagged (t-4) } \\
\text { abolition inter }\end{array}$ & & $\begin{array}{l}-1.574 \\
(2.50)\end{array}$ & $\begin{array}{l}-2.715 \\
(2.16)\end{array}$ & & & \\
\hline $\begin{array}{l}\text { lagged }(\mathrm{t}-4) \\
\text { land cielings }\end{array}$ & & $\begin{array}{r}-0.180 \\
(0.70)\end{array}$ & $\begin{array}{l}0.076 \\
(0.09)\end{array}$ & & & \\
\hline $\begin{array}{l}\text { lagged (t-4) } \\
\text { consolidation land }\end{array}$ & & $\begin{array}{l}-0.194 \\
(0.37)\end{array}$ & $\begin{array}{l}-0.804 \\
(0.79)\end{array}$ & & & \\
\hline $\begin{array}{l}\text { population } \\
\text { growth } \\
\text { rate }\end{array}$ & $\begin{array}{l}-71.49 \\
(0.90)\end{array}$ & $\begin{array}{l}-80.81 \\
(1.29)\end{array}$ & $\begin{array}{l}-92.32 \\
(0.53)\end{array}$ & $\begin{array}{c}-86.725 \\
(1.42)\end{array}$ & $\begin{array}{l}35.203 \\
(0.41)\end{array}$ & $\begin{array}{l}159.47 \\
(0.96)\end{array}$ \\
\hline $\begin{array}{l}\text { lagged (t-4) } \\
\text { p.c. edu exp }\end{array}$ & $\begin{array}{l}0.041 \\
(1.27)\end{array}$ & $\begin{array}{l}0.049 \\
(1.51)\end{array}$ & $\begin{array}{l}0.035 \\
(0.48)\end{array}$ & $\begin{array}{l}0.039 \\
(1.58)\end{array}$ & $\begin{array}{l}0.044 \\
(1.15)\end{array}$ & $\begin{array}{l}-0.020 \\
(0.24)\end{array}$ \\
\hline $\begin{array}{l}\text { lagged (t-4) } \\
\text { p.c. health exp }\end{array}$ & $\begin{array}{l}0.055 \\
(1.09)\end{array}$ & $\begin{array}{l}0.059 \\
(1.14)\end{array}$ & $\begin{array}{l}0.021 \\
(0.18)\end{array}$ & $\begin{array}{l}0.019 \\
(0.55)\end{array}$ & $\begin{array}{l}0.064 \\
(1.09)\end{array}$ & $\begin{array}{l}0.159 \\
(1.15)\end{array}$ \\
\hline $\begin{array}{l}\text { lagged }(\mathrm{t}-4) \\
\text { p.c. other exp }\end{array}$ & $\begin{array}{l}0.015 \\
(1.79)\end{array}$ & $\begin{array}{l}0.013 \\
(1.63)\end{array}$ & $\begin{array}{l}0.020 \\
(1.08)\end{array}$ & $\begin{array}{l}0.015 \\
(3.10)\end{array}$ & $\begin{array}{l}-0.004 \\
(0.47)\end{array}$ & $\begin{array}{l}-0.030 \\
(1.43)\end{array}$ \\
\hline $\begin{array}{l}\text { lagged }(\mathrm{t}-4) \\
\text { p.c. redis state } \\
\quad \operatorname{tax}\end{array}$ & $\begin{array}{l}-0.103 \\
(2.17)\end{array}$ & $\begin{array}{l}-0.115 \\
(2.43)\end{array}$ & $\begin{array}{l}-0.385 \\
(3.45)\end{array}$ & $\begin{array}{c}-0.004 \\
(0.11)\end{array}$ & $\begin{array}{l}-0.148 \\
(2.81)\end{array}$ & $\begin{array}{l}-0.439 \\
(3.23)\end{array}$ \\
\hline $\begin{array}{l}\text { lagged }(\mathrm{t}-4) \text { state } \\
\text { taxes as \% SDP }\end{array}$ & $\begin{array}{l}-63.27 \\
(4.16)\end{array}$ & $\begin{array}{c}-59.085 \\
(3.89)\end{array}$ & $\begin{array}{c}-76.403 \\
(2.26)\end{array}$ & $\begin{array}{l}-29.24 \\
(2.55)\end{array}$ & $\begin{array}{l}-7.85 \\
(0.48)\end{array}$ & $\begin{array}{l}15.055 \\
(0.40)\end{array}$ \\
\hline $\begin{array}{l}\text { lagged }(\mathrm{t}-4) \\
\text { yield }\end{array}$ & $\begin{array}{c}-19.728 \\
(2.88)\end{array}$ & $\begin{array}{c}-18.704 \\
(2.75)\end{array}$ & $\begin{array}{l}-34.17 \\
(2.06)\end{array}$ & $\begin{array}{l}-9.35 \\
(2.58)\end{array}$ & $\begin{array}{l}-5.427 \\
(0.79)\end{array}$ & $\begin{array}{l}-4.673 \\
(0.26)\end{array}$ \\
\hline state effects & YES & YES & YES & YES & YES & YES \\
\hline year effects & YES & YES & YES & YES & YES & YES \\
\hline $\begin{array}{l}\text { no. } \\
\text { obs. }\end{array}$ & 416 & 416 & 416 & 416 & 416 & 416 \\
\hline
\end{tabular}

${ }^{2}$ All regressions are reported with robust standard errors. 
Table 5: Land Policy Determination (t statistics in parenthesis) ${ }^{3}$

\begin{tabular}{|c|c|c|c|c|c|}
\hline & $\begin{array}{l}\text { cum land } \\
\text { reforms }\end{array}$ & $\begin{array}{l}\text { tenancy } \\
\text { reforms }\end{array}$ & $\begin{array}{l}\text { abol } \\
\text { inter }\end{array}$ & $\begin{array}{l}\text { land } \\
\text { cielings }\end{array}$ & $\begin{array}{l}\text { consol } \\
\text { land }\end{array}$ \\
\hline & (1) & (2) & (3) & (4) & (5) \\
\hline model & OLS & OLS & OLS & OLS & OLS \\
\hline $\begin{array}{l}\text { lagged (t-4) } \\
\text { cumulative } \\
\text { land reform }\end{array}$ & $\begin{array}{c}0.406 \\
(12.23)\end{array}$ & & & & \\
\hline $\begin{array}{c}\text { lagged }(\mathrm{t}-4) \\
\text { tenancy reforms }\end{array}$ & & $\begin{array}{c}0.693 \\
(16.26)\end{array}$ & $\begin{array}{l}-0.002 \\
(0.16)\end{array}$ & $\begin{array}{l}-0.009 \\
(0.38)\end{array}$ & $\begin{array}{l}0.021 \\
(1.13)\end{array}$ \\
\hline $\begin{array}{l}\text { lagged (t-4) } \\
\text { abolition inter }\end{array}$ & & $\begin{array}{l}0.041 \\
(0.53)\end{array}$ & $\begin{array}{c}0.664 \\
(14.21)\end{array}$ & $\begin{array}{l}0.109 \\
(1.51)\end{array}$ & $\begin{array}{l}-0.029 \\
(1.06)\end{array}$ \\
\hline $\begin{array}{l}\text { lagged }(\mathrm{t}-4) \\
\text { land cielings }\end{array}$ & & $\begin{array}{l}-0.131 \\
(2.11)\end{array}$ & $\begin{array}{l}-0.172 \\
(0.65)\end{array}$ & $\begin{array}{c}0.631 \\
(15.60)\end{array}$ & $\begin{array}{l}-0.045 \\
(1.44)\end{array}$ \\
\hline $\begin{array}{c}\text { lagged }(\mathrm{t}-4) \\
\text { consolidation land }\end{array}$ & & $\begin{array}{l}0.694 \\
(5.06)\end{array}$ & $\begin{array}{r}-0.038 \\
(1.14)\end{array}$ & $\begin{array}{l}0.174 \\
(2.93)\end{array}$ & $\begin{array}{l}0.772 \\
(7.85)\end{array}$ \\
\hline $\begin{array}{l}\text { lagged }(\mathrm{t}-4) \\
\text { Congress }\end{array}$ & $\begin{array}{l}-0.460 \\
(2.81)\end{array}$ & $\begin{array}{l}-0.472 \\
(4.78)\end{array}$ & $\begin{array}{l}-0.098 \\
(2.37)\end{array}$ & $\begin{array}{l}-0.066 \\
(1.85)\end{array}$ & $\begin{array}{l}-0.075 \\
(1.85)\end{array}$ \\
\hline $\begin{array}{l}\text { lagged (t-4) } \\
\text { hard left }\end{array}$ & $\begin{array}{l}2.837 \\
(2.95)\end{array}$ & $\begin{array}{r}0.476 \\
(0.72)\end{array}$ & $\begin{array}{l}0.149 \\
(0.97)\end{array}$ & $\begin{array}{l}1.437 \\
(5.46)\end{array}$ & $\begin{array}{l}-0.302 \\
(0.73)\end{array}$ \\
\hline $\begin{array}{l}\text { lagged }(\mathrm{t}-4) \\
\text { soft left }\end{array}$ & $\begin{array}{l}-3.921 \\
(3.09)\end{array}$ & $\begin{array}{l}-2.363 \\
(3.25)\end{array}$ & $\begin{array}{l}-1.101 \\
(2.60)\end{array}$ & $\begin{array}{l}-1.990 \\
(3.63)\end{array}$ & $\begin{array}{l}-0.426 \\
(1.06)\end{array}$ \\
\hline $\begin{array}{l}\text { lagged (t-4) } \\
\text { hindu parties }\end{array}$ & $\begin{array}{r}0.270 \\
(0.33)\end{array}$ & $\begin{array}{l}-0.089 \\
(0.19)\end{array}$ & $\begin{array}{l}-0.045 \\
(0.15)\end{array}$ & $\begin{array}{l}0.556 \\
(2.01)\end{array}$ & $\begin{array}{l}-0.410 \\
(2.08)\end{array}$ \\
\hline state effects & YES & YES & YES & YES & YES \\
\hline year effects & YES & YES & YES & YES & YES \\
\hline $\begin{array}{l}\text { Number of } \\
\text { observations }\end{array}$ & 474 & 474 & 474 & 474 & 474 \\
\hline
\end{tabular}

${ }^{3}$ All regressions are reported with robust standard errors. 
Table 6: Land Reform and Poverty in India: Instrumentation $(\mathrm{t} \text { statistics in parenthesis })^{4}$

\begin{tabular}{|c|c|c|c|c|c|c|}
\hline & $\begin{array}{c}\text { rural } \\
\text { pov } \\
\text { gap } \\
(1)\end{array}$ & $\begin{array}{l}\text { rural } \\
\text { head } \\
\text { count } \\
(2)\end{array}$ & $\begin{array}{c}\text { rural } \\
\text { pov } \\
\text { gap } \\
(3)\end{array}$ & $\begin{array}{l}\text { rural } \\
\text { head } \\
\text { count } \\
\text { (4) }\end{array}$ & $\begin{array}{r}\mathrm{PG}_{\mathrm{R}} \\
-\mathrm{PG}_{\mathrm{U}} \\
\\
\\
(5)\end{array}$ & $\begin{array}{c}\mathrm{HC}_{\mathrm{R}} \\
-\mathrm{HC}_{\mathrm{U}} \\
(6)\end{array}$ \\
\hline model & $\mathrm{IV}^{5}$ & IV & IV & IV & IV & IV \\
\hline $\begin{array}{l}\text { lagged (t-4) } \\
\text { cumulative } \\
\text { land reform }\end{array}$ & $\begin{array}{l}-0.732 \\
(6.02)\end{array}$ & $\begin{array}{l}-1.360 \\
(5.68)\end{array}$ & & & $\begin{array}{l}-0.437 \\
(3.60)\end{array}$ & $\begin{array}{l}-1.260 \\
(4.45)\end{array}$ \\
\hline $\begin{array}{l}\text { lagged }(\mathrm{t}-4) \\
\text { tenancy reforms }\end{array}$ & & & $\begin{array}{l}-0.998 \\
(3.16)\end{array}$ & $\begin{array}{l}-2.405 \\
(3.67)\end{array}$ & & \\
\hline $\begin{array}{c}\text { lagged (t-4) } \\
\text { abolition inter }\end{array}$ & & & $\begin{array}{l}-2.271 \\
(2.58)\end{array}$ & $\begin{array}{l}-5.701 \\
(3.65)\end{array}$ & & \\
\hline $\begin{array}{l}\text { lagged }(\mathrm{t}-4) \\
\text { land cielings }\end{array}$ & & & $\begin{array}{l}-1.372 \\
(2.34)\end{array}$ & $\begin{array}{l}0.432 \\
(0.39)\end{array}$ & & \\
\hline $\begin{array}{c}\text { lagged }(\mathrm{t}-4) \\
\text { consolidation land }\end{array}$ & & & $\begin{array}{l}1.624 \\
(1.72)\end{array}$ & $\begin{array}{l}1.969 \\
(1.00)\end{array}$ & & \\
\hline $\begin{array}{c}\text { Sargan overid test } \\
\text { (p-value) }\end{array}$ & $\begin{array}{c}\chi=1.93 \\
(\mathrm{p}=0.99)\end{array}$ & $\begin{array}{c}\chi=1.31 \\
(\mathrm{p}=0.97)\end{array}$ & $\begin{array}{c}\chi=3.28 \\
(\mathrm{p}=0.95)\end{array}$ & $\begin{array}{c}\chi=1.93 \\
(\mathrm{p}=0.99)\end{array}$ & $\begin{array}{c}\chi=2.01 \\
(p=0.92)\end{array}$ & $\begin{array}{r}\chi=1.08 \\
(\mathrm{p}=0.98)\end{array}$ \\
\hline state effects & YES & YES & YES & YES & YES & YES \\
\hline year effects & YES & YES & YES & YES & YES & YES \\
\hline $\begin{array}{l}\text { no. } \\
\text { obs. }\end{array}$ & 410 & 410 & 410 & 410 & 410 & 410 \\
\hline
\end{tabular}

${ }^{4}$ All regressions are reported with robust standard errors.

${ }^{5}$ Instruments for the endogenous policy variable (cumulative land reform lagged four periods) includes share of seats in state assembly occupied by Congress,hard left, soft left and Hindu parties lagged eight periods and land reform variables lagged eight periods (see Table 5 for first stage). 
Table 7: Land Reform and Agricultural Wages (z statistics in parenthesis) ${ }^{6}$

\begin{tabular}{ccc}
\hline \hline & $\begin{array}{c}\text { real agricultural } \\
\text { wages }\end{array}$ & $\begin{array}{c}\text { real agricultural } \\
\text { wages }\end{array}$ \\
\cline { 2 - 3 } model & GLS & $(2)$ \\
\hline AR(1) & GLS \\
& 0.081 & \\
lagged (t-4) & $(2.71)$ & \\
cumulative & & \\
land reform & & 0.049 \\
lagged (t-4) & & $(0.88)$ \\
tenancy reforms & & 0.339 \\
lagged (t-4) & & $(2.61)$ \\
abolition inter & & 0.069 \\
lagged (t-4) & & $(0.09)$ \\
land cielings & & 0.018 \\
lagged (t-4) & & $(0.13)$ \\
consolidation land & & YES \\
state effects & YES & YES \\
year effects & YES & 441 \\
no. & & \\
obs. & 441 & \\
\hline \hline
\end{tabular}

${ }^{6}$ All regressions are reported with robust standard errors. 
Table 8: Land Reform and Growth in India (z statistics in parenthesis) ${ }^{7}$

\begin{tabular}{|c|c|c|c|c|c|}
\hline & $\begin{array}{c}\log \text { state } \\
\text { inc } \\
\text { pc } \\
(1)\end{array}$ & $\begin{array}{c}\log \text { state } \\
\text { ag inc } \\
\text { pc } \\
(2)\end{array}$ & $\begin{array}{c}\log \text { state } \\
\text { ag inc } \\
\text { pc } \\
(3)\end{array}$ & $\begin{array}{c}\text { yield } \\
\text { (ag SDP } \\
\text { /NSA) } \\
(4)\end{array}$ & $\begin{array}{c}\text { yield } \\
\text { (ag SDP } \\
\text { /NSA) } \\
(5)\end{array}$ \\
\hline & $\begin{array}{c}\text { GLS } \\
\text { AR(1) }\end{array}$ & $\begin{array}{l}\text { GLS } \\
\text { AR(1) }\end{array}$ & $\begin{array}{l}\text { GLS } \\
\text { AR(1) }\end{array}$ & $\begin{array}{c}\text { GLS } \\
\text { AR(1) }\end{array}$ & $\begin{array}{l}\text { GLS } \\
\text { AR(1) }\end{array}$ \\
\hline $\begin{array}{l}\text { lagged }(\mathrm{t}-1) \log \\
\text { state inc p.c. }\end{array}$ & $\begin{array}{c}0.497 \\
(12.53)\end{array}$ & & & & \\
\hline $\begin{array}{l}\text { lagged }(\mathrm{t}-1) \log \\
\text { ag state inc p.c. }\end{array}$ & & $\begin{array}{l}0.195 \\
(4.17)\end{array}$ & $\begin{array}{l}0.173 \\
(3.43)\end{array}$ & & \\
\hline $\begin{array}{l}\text { lagged }(\mathrm{t}-4) \\
\text { tenancy reforms }\end{array}$ & $\begin{array}{l}-0.002 \\
(0.43)\end{array}$ & $\begin{array}{l}-0.037 \\
(4.54)\end{array}$ & $\begin{array}{l}-0.032 \\
(2.98)\end{array}$ & $\begin{array}{l}-0.001 \\
(2.49)\end{array}$ & $\begin{array}{l}-0.001 \\
(2.11)\end{array}$ \\
\hline $\begin{array}{l}\text { lagged (t-4) } \\
\text { abolition inter }\end{array}$ & $\begin{array}{l}-0.005 \\
(0.54)\end{array}$ & $\begin{array}{l}0.005 \\
(0.27)\end{array}$ & $\begin{array}{l}-0.017 \\
(0.80)\end{array}$ & $\begin{array}{c}-0.0002 \\
(0.17)\end{array}$ & $\begin{array}{c}-0.0006 \\
(0.35)\end{array}$ \\
\hline $\begin{array}{l}\text { lagged }(\mathrm{t}-4) \\
\text { land cielings }\end{array}$ & $\begin{array}{l}-0.002 \\
(0.22)\end{array}$ & $\begin{array}{l}0.019 \\
(1.26)\end{array}$ & $\begin{array}{l}0.012 \\
(0.64)\end{array}$ & $\begin{array}{r}0.0007 \\
(0.65)\end{array}$ & $\begin{array}{c}0.0004 \\
(0.34)\end{array}$ \\
\hline $\begin{array}{c}\text { lagged (t-4) } \\
\text { consolidation land }\end{array}$ & $\begin{array}{l}-0.013 \\
(1.29)\end{array}$ & $\begin{array}{l}0.065 \\
(3.31)\end{array}$ & $\begin{array}{l}0.056 \\
(2.14)\end{array}$ & $\begin{array}{l}0.003 \\
(2.07)\end{array}$ & $\begin{array}{l}0.003 \\
(1.69)\end{array}$ \\
\hline $\begin{array}{l}\text { population } \\
\text { gr. rate }\end{array}$ & & & $\begin{array}{l}-2.329 \\
(0.68)\end{array}$ & & $\begin{array}{l}0.214 \\
(0.96)\end{array}$ \\
\hline $\begin{array}{l}\text { lagged }(t-4) \\
\text { p.c. edu exp }\end{array}$ & & & $\begin{array}{l}0.003 \\
(1.46)\end{array}$ & & $\begin{array}{l}0.0003 \\
(2.06)\end{array}$ \\
\hline $\begin{array}{l}\text { lagged }(\mathrm{t}-4) \\
\text { p.c. health exp }\end{array}$ & & & $\begin{array}{l}-0.004 \\
(1.92)\end{array}$ & & $\begin{array}{c}-0.0001 \\
(0.61)\end{array}$ \\
\hline $\begin{array}{l}\text { lagged }(\mathrm{t}-4) \\
\text { p.c. other exp }\end{array}$ & & & $\begin{array}{c}-0.0004 \\
(1.16)\end{array}$ & & $\begin{array}{c}-0.00004 \\
(1.11)\end{array}$ \\
\hline $\begin{array}{l}\text { lagged (t-4) } \\
\text { p.c. red st. tax }\end{array}$ & & & $\begin{array}{l}-0.004 \\
(1.55)\end{array}$ & & $\begin{array}{c}-0.0003 \\
(1.27)\end{array}$ \\
\hline $\begin{array}{l}\text { lagged (t-4) state } \\
\text { taxes as \% SDP }\end{array}$ & & & $\begin{array}{l}0.593 \\
(0.74)\end{array}$ & & $\begin{array}{l}0.052 \\
(0.79)\end{array}$ \\
\hline $\begin{array}{l}\text { lagged }(\mathrm{t}-4) \\
\text { yield }\end{array}$ & & & $\begin{array}{l}0.170 \\
(0.66)\end{array}$ & & $\begin{array}{l}0.028 \\
(0.42)\end{array}$ \\
\hline state effects & YES & YES & YES & YES & YES \\
\hline year effects & YES & YES & YES & YES & YES \\
\hline $\begin{array}{l}\text { no. } \\
\text { obs. }\end{array}$ & 484 & 484 & 433 & 488 & 433 \\
\hline
\end{tabular}

${ }^{7}$ All regressions are reported with robust standard errors. 